\title{
Algunhas consideracións sobre o xénero gramatical e o sexismo lingüístico en galego
}

\section{Xoán Carlos Lagares \\ Universidade de Salamanca}

\section{Introdución}

Dunha perspectiva estritamente lingüística o xénero debe ser considerado como unha categoría gramatical que divide os nomes en dous grupos, masculino e feminino, permitíndolles estabelecer relacións de concordancia. Mais, por outra parte, nalgunhas ocasións ese morfema gramatical transmite un determinado contido semántico. Na maioría dos nomes que designan seres animados o xénero gramatical é utilizado como o principal recurso, malia non ser o único, para distinguir cada un dos sexos. Neste traballo veremos os diversos modos de expresar o contido semántico do sexo en galego e a relación que esta dimensión significativa ten coa categoría gramatical do xénero. A seguir, tentaremos delimitar o conceito de sexismo lingüístico téndomos presente o carácter non biunívoco da relación entre xénero gramatical e sexo.

\section{A oposición semántica de sexo na clase dos 'seres humanos'}

O contido semántico do sexo pode ser expresado na clase lexical dos 'seres humanos' das seguintes maneiras:

A. Mediante diferentes lexemas: pai / nai.

B. Mediante unha oposición de morfemas gramaticais de xénero, que, ora en forma de sufixo acrecentado á propria base lexemática, ora recoñecíbel apenas nos morfes expresos no contorno sintáctico do substantivo, estabelece ao mesmo tempo unha oposición gramatical e semántica: neno / nena; $o$ artista / a artista.

Algúns substantivos referidos a seres humanos introducen no seu proprio lexema a información semántica sobre o sexo do ser designado (A), nestes casos o morfema de xénero non acrecenta nengún significado á base lexemática e posúe un contido exclusivamente gramatical. Nestes pares de substantivos prodúcese ás veces o que Coseriu (1981: 57-72) denomina un proceso de neutralización, cando un dos termos da oposición semántica é utilizado no nivel da extensión, o cal supón a desaparición do trazo distintivo. A representación gráfica deste proceso proposta por Coseriu, coa forma que designa o macho englobando a que designa a femia, parécelle limitada a Arias Barredo (1995: 45-58), por canto non fai referencia á oposición privativa que 
se dá no campo intensivo, onde si existe realmente unha oposición semántica de sexo. Distingue portanto este autor entre A e a/b, e toma de Lyons (1971: 466-470) o conceito de hiponimia para definir a relación que se estabelece entre estes dous niveis de análise, de tal maneira que A sería o termo hiperónimo (determinado como genus) entanto que $\mathbf{a} / \mathbf{b}$ (determinados como species) manterían con este termo unha relación de hiponimia e serían cohipónimos entre si.

Débese pór en destaque, neste sentido, o feito de se producir esta neutralización das oposicións lexemáticas de sexo máis frecuentemente no plural do que no singular, onde a forma masculina adoita posuír o sema [- femia]. Así, temos as seguintes neutralizacións:

(1) (a) Pais,// pais I $_{2}$ nais

(b) Padriños 1 / padriños $/$ madriñas

(c) Padrastos $1 / /$ padrasto $_{2} /$ madrastas

(d) Xenros $1 / /$ xenros $_{2} /$ noras $^{1}$

As formas masculinas en singular, pai, padriño, padrasto, xenro, son encadradas case sempre, se non existir algunha especificación ulterior ou un contexto totalmente clarificador, no nivel ${ }_{2}$, posuíndo o sema [- femia] e opóndose ás respectivas formas que neste nivel posúen o sema [+ femia]: nai, madriña, madrasta, nora ${ }^{2}$. Pódese explicar esta neutralización no plural pola necesidade de expresar o que é común a cada un dos termos do par opositivo. No singular, no entanto, prodúcense máis facilmente enunciados ambiguos, de onde resulta a necesidade de marcarmos con claridade a presenza ou non de contido sexual no lexema:

(2) (a) Non asistiu nengún pai á reunión organizada no colexio.

(b) Non asistiron os pais á reunión organizada no colexio.

(c) Non asistiron pais nen nais á reunión organizada no colexio.

A oración (2a) pode significar que non asistiu nengún pai, mais si algunha nai, interpretándoo no nivel ${ }_{2}$, ou ben que non asistiron nen pais nen nais, no nivel ${ }_{1}$. Isto é o que expresa claramente a oración (2c), que por iso é preferíbel neste tipo de enunciados. Se a situación comunicativa non permitir coñecer con exactitude o referente do substantivo pais, tamén este plural do exemplo (2b) pode manter unha certa ambigüidade, que, neste sentido, só se produce no masculino, por ser esta a única forma que pode funcionar en dous diferentes

1 Do par home/ muller, que a este respeito adoita comportarse dun xeito particular, ocuparémonos pormenorizadamente máis adiante, ao analisarmos os posíbeis enunciados sexistas (vid. 2.2.).

2 A necesidade de discernir o significado intensivo ou extensivo do substantivo segundo o contexto lingüístico en que se produce o enunciado foi posta de manifesto por Vila Pujol (1989), que distingue entre casos de particularización e xeneralización do substantivo, tanto en singular como en plural, sendo diferentes as posibilidades de neutralización do masculino en cada un dos casos. 
niveis de significado ${ }^{3}$. Frecuentemente, é o contexto en que aparece o substantivo o indicador máis fiel para a súa correcta interpretación:

(3) $O$ pai $_{2}$ anda decindo:

-Non volve porque como a nai é así.. .

E a nai anda decindo:

-Non volve porque como o pai ${ }_{2}$ é así...

Pero eu sei que non volve porque aínda non é dabondo rico para mata-las risas dos que se moufan dos seus pais,; que con diñeiro pódese chegar a Excelentísimo señor, según xa ten pasado e aínda pasará.

(Castelao, Cousas 68)

Por outra parte, existen unicamente dous pares de substantivos de persoa opostos polo contido semántico do sexo en que nengún dos termos serve como elemento neutralizado desa oposición (non habendo tampouco un terceiro termo arquilexemático): cabaleiro / dama, macho / femia. Como xa indicamos, nestes exemplos que estamos a tratar a oposición de sexo está presente nos proprios lexemas, cumprindo os morfemas de xénero que posúen estes substantivos, recoñecíbeis no contorno sintáctico por meio da concordancia, unha función exclusivamente gramatical.

No tocante á oposición sexual expresada por meio dun morfema de xénero (B), isto é, cando este morfema ten tamén un contido semántico, a neutralización da oposición de significado realízase en todos os casos no termo masculino, que funciona como hiperónimo ou termo extensivo da oposición, de acordo co seguinte esquema: neno // neno / nena. Pódese distinguir portanto neno ${ }_{1}$ e $n e n o_{2}$, entendendo que neno, é o termo hiperónimo (en terminoloxía de Coseriu, neutralizado, extensivo) e neno 2 é o termo hipónimo (intensivo). De acordo co modelo de análise que seguimos, consideramos que no nivel ${ }_{1}$, no da extensión, o morfema de xénero destes nomes ten un contido exclusivamente gramatical, entanto que no nivel ${ }_{2}$, sen perder ese carácter gramatical, achega tamén un contido semántico lexical, por servir como marca da distinción de sexos.:

(4) (a)

Vim mozos $_{2}$, vim mozas, vim homes $_{2}$, vim vellos vim muitas mulleres, vim nenas, vim nenos . $_{2}$

(Sarmiento, Coloquio 86)

\footnotetext{
O termo extensivo, por ser tamén intensivo noutro nivel da súa significación, ten o duplo de ocorrencias que o outro termo da oposición. Ás veces a utilización dos dous termos da oposición responde a causas estilísticas, de énfase, constituíndo en ocasións frases feitas: unha rapaza criada pola caridá de todos que aparecera dentro dun queipo, a carón dun cruceiro, que non tiña pai nin nai, nin por quen chorar (Castelao, Cousas 22)
} 
(b)

¡Vinde vel-a, mociños, e mozas!

¡Saludáina, rapaces ${ }_{1}$ e vellos ${ }_{1}$ !

(Curros, AMT 135)

(c)

Vellos, e vellas, mentres monean

Silvan as salves y os padres nuestros

(Rosalía, FN 28)

(d)

Rapazas e rapaces $_{2}$, uns pequeneiros, outros xa langranotes, amoreábanse no monte das Gafas

(Otero, $M E$ 15)

(e)

Dous vellos, que tamén tiveron mocedade, que se coñeceron nun baile, que logo se casaron por amor e que viviron amándose tolamente.

[...]

Antonte leváronlle o viático ó vello ${ }_{2}$ e onte morreu.

(Castelao, Cousas 37)

(f)

Non hai escola en Balde, circunstáncia hoxe xustificada porque xa non hai nenos, que necesiten estudar, pero tampouco hai caixa de aforros, nen centro de saúde, ainda que si hai vellos, que precisan deses servizos.

(Vixande, ANT 11-11-99)

Nestes exemplos temos diversas oposicións semánticas, e non todas se sustentan na referencia á distinción sexual. No exemplo (4b) opóñense semanticamente polo sexo mociñas e mozos no primeiro dos versos, mais no segundo a oposición realízase no nivel dos hiperónimos sobre a dimensión 'idade': rapaces e vellos, ficando a dimensión semántica do sexo neutralizada, inoperante do ponto de vista do significado, se ben estes substantivos son tamén capaces de apresentaren oposición sexual no plural, como pode verse nos exemplos (4c) e (4d): vellos e vellas, rapazas e rapaces. Son razóns de índole pragmática, e nos textos literarios fundamentalmente estilísticas, as que motivan a expresión de determinadas oposicións. Como ocorría cos nomes que expresaban lexematicamente a oposición sexual, tamén nestes morfemas se producen aproximadamente o duplo de ocorrencias da forma masculina, ao mesmo tempo extensiva e intensiva, podendo en ocasións provocar esta polisemia unha certa ambigüidade en determinados contextos. Un dos procedimentos utilizados para resolver esa ambigüidade significativa é o de adxuntar ao nome algún outro substantivo que sirva como 
indicador do sexo, cando se quer facer referencia a un ou outro sexo, ou ben utilizar ambos os termos da oposición. Véxase, neste sentido, este texto xornalístico de Marina Mayoral intitulado “¿Neno ou nena?”:

(5)

Segundo un artigo divulgativo que me mandou unha amiga norteamericana, ali a elección está limitada ás familias que xa teñen un fillo, para evitar que o primoxénito sexa sempre varón. Parece que esta preferencia é case xeral. Máis dun noventa por cento de parellas de todo o mundo prefiren un primeiro fillo varón ${ }^{4}$

O cohipónimo masculino, o termo intensivo, pode aparecer marcado mediante o substantivo varón, non sendo necesaria como é obvio un especificación deste tipo para a correspondente forma feminina, que só pode funcionar no nivel intensivo, segundo este esquema: fillo ${ }_{1} / /$ fillo varón / filla:

(6) (a) O meu primeiro fillo foi un neno ${ }_{2}$.

(b) $\mathrm{O}$ meu primeiro fillo, foi unha nena ${ }_{2}$.

Contrariamente, non son posíbeis enunciados como 'A miña primeira filla foi un neno', ou mesmo 'A miña primeira filla foi unha nena'. Este último enunciado é redundante, pois o substantivo filla posúe sempre o sema [+ femia], motivo polo cal se considera que o termo marcado da oposición en galego é aquel que posúe morfema de xénero feminino. Un procedimento similar utilízase ás veces para especificar o sexo naqueles nomes de persoa que apresentan sincretismo formal entre masculino e feminino, cando o contexto sintáctico en que habitualmente se substancia a expresión do morfema de xénero non axuda para o identificar:

(7) (a) Estivemos viaxando cun grupo de mulleres futbolistas.

(b) Estivemos viaxando cun grupo de futbolistas femininas.

(c) Estivemos viaxando cun grupo de homes futbolistas.

(d) Estivemos viaxando cun grupo de futbolistas masculinos.

Este caso debe ser interpretado de modo diverso que o de fillo, pois aquí sendo a forma extensiva a masculina (o futbolist $a_{1} / /$ o futbolista $a_{2}$ a futbolista), é máis

4 O DRAG (1998: s.v.) non recomenda o uso do substantivo varón en galego, e remete para home como única forma correcta. Pola súa parte, as dúas primeiras acepcións de home son as seguintes: "Animal da especie humana, a máis evolucionada da Terra, que se caracteriza fundamentalmente por adopta-la posición vertical, ter linguaxe articulada, intelixencia moi desenvolvida e facultade de razoar", e "Individuo da especie humana, de sexo masculino". No DAE (1994: s.v.) rexístrase unha forma varão con este último significado: "Indíviduo do sexo masculino", definición que coincide coa do DLP (1992: s.v.). 
habitualmente a feminina (a futbolista) a que precisa ser especificada (12a e 12b). A explicación corresponde non á semántica gramatical senón á semántica de uso, á pragmática, e ten a ver con fenómenos sociais como a incorporación da muller a todo o tipo de traballos e actividades antes realizadas unicamente por homes. Neste sentido, a lingua é un indicador das mudanzas que se producen na sociedade e do modo en que se desenvolven, ademais de transmitir contidos ideolóxicos e de exprimir en moitas ocasións a forma en que se articula o noso coñecimento e as nosas expectativas perante o mundo.

Outras veces este fenómeno vén causado por unha maior complexidade da estrutura semántica do xénero en determinados substantivos, dados os diferentes significados que poden adquirir os morfemas de xénero masculino e feminino. Desta maneira, no par opositivo o policía ${ }_{2} /$ a policía $a_{2}$ podemos distinguir dous termos hiperónimos opostos pola dimensión [ \pm abstracto]: o policía $a_{1}$ a policía onde o policía é o termo neutralizado que fai referencia á persoa sen distinguir o seu sexo ('Non apareceu nengún policía ${ }_{1}$ no momento do accidente'), e a policía designa o corpo de policía, a institución. Por iso ás veces faise necesario indicar mediante algún outro procedimento lexical, normalmente adxuntando o substantivo muller, que se está a falar no nivel ${ }_{2}$, facéndose referencia ao cohipónimo feminino, de acordo co seguinte esquema:

(8) (a) o policía $a_{1}$ os policías $\left.)_{1}\right) /$ a policía

(b) o policía $/$ a muller policía

Xeralmente, os nomes de profisións oferecen indicacións moi precisas sobre a realidade social, sendo diversas as solucións adoptadas para expresar as diferenzas sexuais. A terminación do substantivo é interpretada nalgunhas ocasións como se for un morfe xenérico, realizándose entón a flexión para o feminino mediante a conmutación da vogal polo sufixo - $a$ ou ben mediante o seu acrecentamento, pois o - $a$ foi considerado desde moi cedo como caracterizador do feminino: xuíza, avogada, decana, médica, enxeñeira, ministra, etc. ${ }^{5}$ :

(9) (a)

Pero certamente, é necesario acceder a todos os oficios e servicios técnicos que están reservados só aos homes. En lugar de secretaria, fontaneira, mecánica, albanela.

(Queizán, Voz, 22-11-99)

\footnotetext{
Os dicionarios e as normas lingüísticas non sempre recollen estas formas (que xa non son tan novas). Por outra parte, esta tendencia a marcar mediante un sufixo - $a$ a forma feminina está presente no idioma desde a Idade Media (de feito, ten a súa orixe no proprio latín: lupus/lupa), e explica resultados actuais como señora, portuguesa, etc. Ás veces unha realidade social nova pode causar certa inestabilidade no modo de expresar lingüisticamente o sexo dos referentes de determinados substantivos de oficio. Así, frente ao xa habitual substantivo feminino decana, temos escoitado nalgunha ocasión a un falante de idade avanzada utilizar a forma decano muller; noutras ocasións indícase o sexo mediante un morfema de xénero expreso só na concordancia e non nun morfe ligado ao lexema: o decano / a decano.
} 
(b)

A ministra de Meio Ambiente, Isabel Tocino, visitou Galiza o pasado Mércores 3 de Novembro

(ANT, 11-11-99)

\begin{abstract}
Noutros substantivos mantense unha certa inestabilidade nos usos (a cliente $\sim a$ clienta; a presidente $\sim$ a presidenta), se ben a tendencia é a de marcar sempre mediante o sufixo a forma feminina ${ }^{6}$. Na realidade, é esta unha posibilidade do sistema que se pode pór en práctica con diferentes motivacións ideolóxicas ou estilísticas, estiver ou non sancionado nun principio o seu uso pola norma, segundo a xa clásica distinción proposta por Coseriu (1981: 123-130)7 . O sistema lingüístico do galego permite distinguir sempre o xénero mediante sufixos ligados ao lexema, aínda que resulte pouco habitual e este procedimento non estexa fixado na norma, coas máis diversas intencións estilísticas: lúdicas, reivindicativas, etc. De tal maneira que é posíbel ouvir en determinados contextos comunicativos formas como membra, tipa (e mesmo macha), individua, etc ${ }^{8}$. Son causas extralingüísticas
\end{abstract}

* González Fernández (1978: 184-185), no entanto, afirma o seguinte ao respeito: "Además en las funciones de oficio, el masculino designa la función independiente a toda noción de sexo: catedrático, sirve de nombre de agente a la vez al hombre y a la mujer, pasando a ser término genérico. Para Dubois, el movimiento general que lleva en la actualidad a usar el masculino en los nombres de oficio tiene causas sociales, debido a la tendencia a suprimir las diferencias entre el trabajo del hombre y de la mujer. Esto repercute a la lengua, y aunque podemos decir catedrática, hay casos, como -al, -ante, -ista, que son el mismo sufijo para el masculino que para el femenino, y así se dice concellal, cantante, carteirista tanto para referirnos al hombre o a la mujer que tienen este oficio, y no *concellala, *cantanta, *carteiristo". Do noso ponto de vista, con estes últimos exemplos oférecese unha visión simplificada do que na realidade é máis complexo, pois, entre outras cousas, non dá conta de formas como clienta, presidenta, etc, habituais no galego de hoxe. Doutra parte, a afirmación sobre a tendencia a usar o masculino para os nomes de oficio e a súa explicación non parecen axeitadas para a realidade de uso actual, talvez por se basear en Dubois, cuxas argumentacións están referidas ao francés, lingua en que o funcionamento do xénero nestes casos é levemente diferente ao do galego.

7 "Como corolario, la norma es un conjunto formalizado de realizaciones tradicionales; abarca lo que ya "existe", lo que ya se ha realizado en la tradición lingüística. El sistema, por el contrario, es un conjunto de posibilidades de realización: abarca también lo que no se ha realizado aún, pero que es virtualmente existente, lo que es "posible", es decir, lo que puede ser creado de acuerdo con las reglas funcionales de la lengua" (Coseriu 1981: 126).

8 O uso masculino en formas habitualmente femininas, representado non apenas pola concordancia senón tamén polo morfe -o, pode ter ás veces unha intención estilística determinada, despectiva ou simplesmente paródica: ¿Con que ti eres un poetiso vergonzante? ¿De que rapaza eres muso? ¿Non reparaches nunca que tes un misterioso sorriso de Giocondo? (Fole, ALC 75). Véxase neste sentido tamén o adxectivo laverco/-a, criado a partir do substantivo feminino e invariábel canto ao xénero laverca, e que no entanto posúe flexión xenérica. Doutro lado, o sufixo -as utilizado para formar adxectivos depreciativos (conas, trolas, merdas...) pode supor unha caracterización mórfica feminina de nomes referidos a homes e de xénero masculino (que manteñen contodo o seu xénero: un conas, un trolas, un merdas). Este sufixo pode aparecer tamén asociado aos sufixos -allo (bardallas) e -ico (mexericas) (cfr. Ferreiro 1997: 145-146): ou o Setesaias, ou o Maricallas (Blanco Amor, OGC I 21 ). Por último, a reinterpretación mórfica das terminacións dos nomes está relacionada ás veces coa tendencia regularizadora da linguaxe infantil, que pretende facer todos os masculinos terminaren en -o e todos os femininos terminaren en $-a$. Neste sentido, temos presenciado unha situación en que unha cativa chamaba a un amigo da súa mesma idade idioto. 
as que determinan as especializacións de significado que acompañan en ocasións estas novas formas, así como a consideración depreciativa que poden adquirir. Así, por exemplo, non parece ser moi forte a tendencia a flexionar mediante un sufixo o substantivo estudante (estudanta), sendo a marca máis frecuente para o feminino o artigo correspondente ( $a$ estudante). A causa podería fundarse nun antigo matiz despectivo aplicado a este substantivo para designar nunha determinaba altura histórica as mulleres que ousaban estudar, e que nunha sociedade sexista e androcéntrica eran minoría, o cal inhibiría o seu uso co morfe proprio do feminino a favor dunha expresión xenérica exclusivamente sintáctica. Son tamén causas extralinguísticas as que explican a falta de simetría entre a forma masculina e a feminina no significado de determinados substantivos, que exemplificamos con apenas dúas oposicións que consideramos moi representativas:

(10) (a) asistente / asistenta

(b) modista / modisto

En (10a) temos unha forma feminina asistenta que designa habitualmente a persoa que realiza traballos domésticos, referida, obviamente, a mulleres, se ben a masculina fai referencia só ao home ou ben á persoa que asiste a un lugar ou que axuda nun determinado labor:

(11) (a) Os asistentes ao acto encheron o local

(b) As asistentes ao acto encheron o local

(c) *As asistentas ao acto encheron o local

A forma masculina plural de (11a) podería ser analisada como pertencente ao nivel ou ao nivel ${ }_{2}$, como termo intensivo ou como extensivo, entanto que a forma de (11b) só pode ser analisada no nivel da intensión e fai referencia exclusivamente a persoas do sexo feminino. A forma asistentas de (11c) posúe no entanto un significado diferente que non lle permite ser utilizado neste enunciado (coa especificación ao acto), pois significa 'muller que realiza traballos domésticos por conta allea' e é sinónimo de criadas e serventas. O feito de non funcionar este significado cando aplicada a homes é proba dunha realidade social discriminatoria, mais a desigualdade non se produce inicialmente no seo da lingua, que non constitúe máis do que un reflexo desa situación?

O caso de (10b) é sensibelmente diferente, pois é a partir da forma feminina, usada en primeiro lugar, que se criou unha forma masculina, trocando o - $a$ final, reinterpretado como morfe de xénero feminino, polo -o que representa morficamente o masculino. Mais nesta ocasión a forma masculina especializou o

9 O DRAG (1998: s.v.) inclúe a seguinte observación: "É infrecuente o uso do masculino cando se refire á persoa que realiza traballos domésticos". Seguramente, o que resulta realmente infrecuente é que un home realice tais traballos, de aí que non se use a forma masculina con esa acepción. 
seu significado cun uso diferente, pasando a ser sinónimo de deseñador (aplicado fundamentalmente a criadores de alta costura), entanto que a forma feminina, modista, continuou a ser empregada máis comunmente como sinónimo de costureira. Por ficar o substantivo feminino reservado para este uso, a muller que realiza deseños de roupa é denominada normalmente deseñadora e non modista, apesar de existir tamén esa posibilidade no sistema ${ }^{10}$. O que pon de manifesto tal desequilibrio nos significados dos termos flexionados dun mesmo substantivo (modista / modisto) é unha realidade socio-económica desigual no tocante á relación entre o sexo e a división do traballo na nosa sociedade. Outros nomes de profisións ou cargos que antigamente designaban na súa forma feminina a esposa dos homes que os exercían, van perdendo na actualidade este significado para facer referencia simplesmente á muller que realiza estas funcións (alcaldesa, sarxenta, capitá, etc). O feito de existiren formas femininas mesmo antes de haber mulleres que exercesen estas profisións ou cargos pon de manifesto, así mesmo, a rendibilidade do mecanismo flexional de xénero, que ten a posibilidade de adquirir os máis diversos significados lingüísticos, normalmente en relación coa distinción sexual (mais non só). A interpretación da terminación do substantivo como expresión mórfica de xénero existe, segundo estamos vendo, como unha posibilidade máis do sistema, podendo ser diversas as significacións -e sobretodo as connotacións- que encerre, de acordo coas necesidades comunicativas que se formen dentro da estrutura social en que son utilizadas en cada momento histórico.

Hai, aliás, outros factores que poden influír na utilización ou non dun sufixo específico para exprimir o xénero feminino dun substantivo no nivel da intensión, entre os cais debemos destacar a posíbel polisemia que resulta desas formas femininas cun sufixo $-a$. De todos os xeitos, a polisemia é un recurso moi estendido na nosa lingua, sen que noutras ocasións se produza calquer efeito de anulación dun dos significados dun determinado substantivo. Neste sentido, xa vimos ser perfeitamente asumida a polisemia da forma masculina nestes pares opositivos, sendo o contexto en que se insere o substantivo quen permite distinguir se está a ser utilizado no nivel intensivo ou no extensivo". Podemos supor, portanto, que son novamente causas extralingüísticas as que inhiben en ocasións o uso das formas femininas que debían ser normais, como mecánica, política, química, física, no nivel $\mathrm{l}_{2}$ (intensivo) da oposición, en favor de formas como a mecánico, a político, a químico, a físico.

${ }^{10}$ Por este motivo parece discutíbel a apreciación de Arias Barredo (1995: 51) sobre o carácter extensivo para o español do substantivo modista $a_{1}$, realizado no nivel intensivo da oposición sexual como modista $a_{2}+$ modisto. Véxase o que a este respeito afirma Nissen: "As a matter of fact, it represents an example of linguistic male dominance par excellence” (1986: 734-736).

1 Para Ullmann (1987: 347) a polisemia resulta un mecanismo económico e rendíbel mercé á influencia que exerce o contexto para clarificar o significado das palabras: "Como funciona na prática este delicado mecanismo? A principal garantia do seu funcionamento normal é a influência do contexto. Não interessa o número de significados que uma palabra possa ter no dicionário; não haverá confusão se apenas um deles fizer sentido numa dada situação". 


\section{O conceito de sexismo lingüístico}

\subsection{Sistema de xénero e sexismo lingüístico}

Temos analisado até aquí o xénero gramatical desde unha óptica que se podería definir como formalista, considerándoo un morfema gramatical (cunha dimensión, portanto, morfosintáctica) que clasifica os nomes en dous grupos e que permite estabelecer relacións de concordancia. É nun segundo momento que se debe abordar o estudo do seu contido semántico, funcionando nestes casos ese morfema gramatical como se se tratar dun morfema lexical, por canto acrecenta información semántica á base lexemática con que concorre. A dimensión do sexo é a que alcanza maior relevancia nas oposicións semánticas que se poden estabelecer através do morfema categorial do xénero; nestas ocasións os procesos de neutralización semántica prodúcense en favor da forma masculina, que funciona a este respeito como forma extensiva, non marcada. Do noso ponto de vista, a neutralización supón que o contido sexual do morfema de xénero fica en suspenso, e ao non servir este morfema como indicador da distinción sexual perde tamén o seu carácter lexical, conservando exclusivamente a función gramatical que o define como categoría morfosintáctica. Neste sentido, entendemos que o morfema de xénero do termo masculino no nivel da extensión (neno $)_{1}$ ) ten apenas un significado gramatical, equivalente ao que poida estar presente en calquer outro substantivo sen motivación semántica de xénero (castiñeiro). Esta perspectiva de análise susténtase sobre a distinción conceptual previa entre xénero gramatical e sexo (tamén entre xénero gramatical e xénero, entendido este último como a variábel cultural do sexo biolóxico). Tal distinción, que foi marcada dun xeito explícito por vez primeira polas correntes estruturalistas e funcionalistas, e que desde o paradigma xerativista se considera fundamental, non era habitual nos estudos lingüísticos previos e vén sendo contestada recentemente por varios autores desde presupostos teóricos e ámbitos de análise diversos ${ }^{12}$.

A identificación total entre o xénero gramatical e a distinción sexual ten suscitado un agudo desconcerto por causa da arbitrariedade con que esta categoría se reparte entre as linguas do mundo, provocando aparentes incongruencias, tais como a súa aplicación a nomes da clase [- animado] ou como a asignación da clase nominal feminina a substantivos que poden facer referencia tamén a nomes de seres caracterizados polo sema [- femia] (sentinela, persoa, testemuña, etc.). Esta cuestión débese pór en relación, aliás, co problema da orixe da categoría nas linguas indoeuropeas, servindo como elemento de comparación os idiomas pertencentes a outras familias lingüísticas. Frente ás hipóteses que sitúan a orixe desta categoría nunha primixenia tentativa por ordenar todos os seres e obxectos do

12 As críticas desta visión formalista do xénero lingüístico proceden fundamentalmente do terreno da antropoloxía e mesmo da socioloxía e baséanse, como veremos máis adiante, no simbolismo dos xéneros. 
Algunhas consideracións sobre o xénero gramatical e o sexismo lingüístico en galego

Xoán Carlos Lagares

Universidade de Salamanca

\section{Introdución}

Dunha perspectiva estritamente lingüística o xénero debe ser considerado como unha categoría gramatical que divide os nomes en dous grupos, masculino e feminino, permitíndolles estabelecer relacións de concordancia. Mais, por outra parte, nalgunhas ocasións ese morfema gramatical transmite un determinado contido semántico. Na maioría dos nomes que designan seres animados o xénero gramatical é utilizado como o principal recurso, malia non ser o único, para distinguir cada un dos sexos. Neste traballo veremos os diversos modos de expresar o contido semántico do sexo en galego e a relación que esta dimensión significativa ten coa categoría gramatical do xénero. A seguir, tentaremos delimitar o conceito de sexismo lingüístico téndomos presente o carácter non biunívoco da relación entre xénero gramatical e sexo.

\section{A oposición semántica de sexo na clase dos 'seres humanos'}

O contido semántico do sexo pode ser expresado na clase lexical dos 'seres humanos' das seguintes maneiras:

A. Mediante diferentes lexemas: pai / nai.

B. Mediante unha oposición de morfemas gramaticais de xénero, que, ora en forma de sufixo acrecentado á propria base lexemática, ora recoñecíbel apenas nos morfes expresos no contorno sintáctico do substantivo, estabelece ao mesmo tempo unha oposición gramatical e semántica: neno / nena; $o$ artista / a artista.

Algúns substantivos referidos a seres humanos introducen no seu proprio lexema a información semántica sobre o sexo do ser designado (A), nestes casos o morfema de xénero non acrecenta nengún significado á base lexemática e posúe un contido exclusivamente gramatical. Nestes pares de substantivos prodúcese ás veces o que Coseriu (1981: 57-72) denomina un proceso de neutralización, cando un dos termos da oposición semántica é utilizado no nivel da extensión, o cal supón a desaparición do trazo distintivo. A representación gráfica deste proceso proposta por Coseriu, coa forma que designa o macho englobando a que designa a femia, parécelle limitada a Arias Barredo (1995: 45-58), por canto non fai referencia á oposición privativa que 
se dá no campo intensivo, onde si existe realmente unha oposición semántica de sexo. Distingue portanto este autor entre A e a/b, e toma de Lyons (1971: 466-470) o conceito de hiponimia para definir a relación que se estabelece entre estes dous niveis de análise, de tal maneira que A sería o termo hiperónimo (determinado como genus) entanto que $\mathbf{a} / \mathbf{b}$ (determinados como species) manterían con este termo unha relación de hiponimia e serían cohipónimos entre si.

Débese pór en destaque, neste sentido, o feito de se producir esta neutralización das oposicións lexemáticas de sexo máis frecuentemente no plural do que no singular, onde a forma masculina adoita posuír o sema [- femia]. Así, temos as seguintes neutralizacións:

(1) (a) Pais,// pais I $_{2}$ nais

(b) Padriños 1 / padriños $/$ madriñas

(c) Padrastos $1 / /$ padrasto $_{2} /$ madrastas

(d) Xenros $1 / /$ xenros $_{2} /$ noras $^{1}$

As formas masculinas en singular, pai, padriño, padrasto, xenro, son encadradas case sempre, se non existir algunha especificación ulterior ou un contexto totalmente clarificador, no nivel ${ }_{2}$, posuíndo o sema [- femia] e opóndose ás respectivas formas que neste nivel posúen o sema [+ femia]: nai, madriña, madrasta, nora ${ }^{2}$. Pódese explicar esta neutralización no plural pola necesidade de expresar o que é común a cada un dos termos do par opositivo. No singular, no entanto, prodúcense máis facilmente enunciados ambiguos, de onde resulta a necesidade de marcarmos con claridade a presenza ou non de contido sexual no lexema:

(2) (a) Non asistiu nengún pai á reunión organizada no colexio.

(b) Non asistiron os pais á reunión organizada no colexio.

(c) Non asistiron pais nen nais á reunión organizada no colexio.

A oración (2a) pode significar que non asistiu nengún pai, mais si algunha nai, interpretándoo no nivel ${ }_{2}$, ou ben que non asistiron nen pais nen nais, no nivel ${ }_{1}$. Isto é o que expresa claramente a oración (2c), que por iso é preferíbel neste tipo de enunciados. Se a situación comunicativa non permitir coñecer con exactitude o referente do substantivo pais, tamén este plural do exemplo (2b) pode manter unha certa ambigüidade, que, neste sentido, só se produce no masculino, por ser esta a única forma que pode funcionar en dous diferentes

1 Do par home/ muller, que a este respeito adoita comportarse dun xeito particular, ocuparémonos pormenorizadamente máis adiante, ao analisarmos os posíbeis enunciados sexistas (vid. 2.2.).

2 A necesidade de discernir o significado intensivo ou extensivo do substantivo segundo o contexto lingüístico en que se produce o enunciado foi posta de manifesto por Vila Pujol (1989), que distingue entre casos de particularización e xeneralización do substantivo, tanto en singular como en plural, sendo diferentes as posibilidades de neutralización do masculino en cada un dos casos. 
niveis de significado ${ }^{3}$. Frecuentemente, é o contexto en que aparece o substantivo o indicador máis fiel para a súa correcta interpretación:

(3) $O$ pai $_{2}$ anda decindo:

-Non volve porque como a nai é así.. .

E a nai anda decindo:

-Non volve porque como o pai ${ }_{2}$ é así...

Pero eu sei que non volve porque aínda non é dabondo rico para mata-las risas dos que se moufan dos seus pais,; que con diñeiro pódese chegar a Excelentísimo señor, según xa ten pasado e aínda pasará.

(Castelao, Cousas 68)

Por outra parte, existen unicamente dous pares de substantivos de persoa opostos polo contido semántico do sexo en que nengún dos termos serve como elemento neutralizado desa oposición (non habendo tampouco un terceiro termo arquilexemático): cabaleiro / dama, macho / femia. Como xa indicamos, nestes exemplos que estamos a tratar a oposición de sexo está presente nos proprios lexemas, cumprindo os morfemas de xénero que posúen estes substantivos, recoñecíbeis no contorno sintáctico por meio da concordancia, unha función exclusivamente gramatical.

No tocante á oposición sexual expresada por meio dun morfema de xénero (B), isto é, cando este morfema ten tamén un contido semántico, a neutralización da oposición de significado realízase en todos os casos no termo masculino, que funciona como hiperónimo ou termo extensivo da oposición, de acordo co seguinte esquema: neno // neno / nena. Pódese distinguir portanto neno ${ }_{1}$ e $n e n o_{2}$, entendendo que neno, é o termo hiperónimo (en terminoloxía de Coseriu, neutralizado, extensivo) e neno 2 é o termo hipónimo (intensivo). De acordo co modelo de análise que seguimos, consideramos que no nivel ${ }_{1}$, no da extensión, o morfema de xénero destes nomes ten un contido exclusivamente gramatical, entanto que no nivel ${ }_{2}$, sen perder ese carácter gramatical, achega tamén un contido semántico lexical, por servir como marca da distinción de sexos.:

(4) (a)

Vim mozos $_{2}$, vim mozas, vim homes $_{2}$, vim vellos vim muitas mulleres, vim nenas, vim nenos . $_{2}$

(Sarmiento, Coloquio 86)

\footnotetext{
O termo extensivo, por ser tamén intensivo noutro nivel da súa significación, ten o duplo de ocorrencias que o outro termo da oposición. Ás veces a utilización dos dous termos da oposición responde a causas estilísticas, de énfase, constituíndo en ocasións frases feitas: unha rapaza criada pola caridá de todos que aparecera dentro dun queipo, a carón dun cruceiro, que non tiña pai nin nai, nin por quen chorar (Castelao, Cousas 22)
} 
(b)

¡Vinde vel-a, mociños, e mozas!

¡Saludáina, rapaces ${ }_{1}$ e vellos ${ }_{1}$ !

(Curros, AMT 135)

(c)

Vellos, e vellas, mentres monean

Silvan as salves y os padres nuestros

(Rosalía, FN 28)

(d)

Rapazas e rapaces $_{2}$, uns pequeneiros, outros xa langranotes, amoreábanse no monte das Gafas

(Otero, $M E$ 15)

(e)

Dous vellos, que tamén tiveron mocedade, que se coñeceron nun baile, que logo se casaron por amor e que viviron amándose tolamente.

[...]

Antonte leváronlle o viático ó vello ${ }_{2}$ e onte morreu.

(Castelao, Cousas 37)

(f)

Non hai escola en Balde, circunstáncia hoxe xustificada porque xa non hai nenos, que necesiten estudar, pero tampouco hai caixa de aforros, nen centro de saúde, ainda que si hai vellos, que precisan deses servizos.

(Vixande, ANT 11-11-99)

Nestes exemplos temos diversas oposicións semánticas, e non todas se sustentan na referencia á distinción sexual. No exemplo (4b) opóñense semanticamente polo sexo mociñas e mozos no primeiro dos versos, mais no segundo a oposición realízase no nivel dos hiperónimos sobre a dimensión 'idade': rapaces e vellos, ficando a dimensión semántica do sexo neutralizada, inoperante do ponto de vista do significado, se ben estes substantivos son tamén capaces de apresentaren oposición sexual no plural, como pode verse nos exemplos (4c) e (4d): vellos e vellas, rapazas e rapaces. Son razóns de índole pragmática, e nos textos literarios fundamentalmente estilísticas, as que motivan a expresión de determinadas oposicións. Como ocorría cos nomes que expresaban lexematicamente a oposición sexual, tamén nestes morfemas se producen aproximadamente o duplo de ocorrencias da forma masculina, ao mesmo tempo extensiva e intensiva, podendo en ocasións provocar esta polisemia unha certa ambigüidade en determinados contextos. Un dos procedimentos utilizados para resolver esa ambigüidade significativa é o de adxuntar ao nome algún outro substantivo que sirva como 
indicador do sexo, cando se quer facer referencia a un ou outro sexo, ou ben utilizar ambos os termos da oposición. Véxase, neste sentido, este texto xornalístico de Marina Mayoral intitulado “¿Neno ou nena?”:

(5)

Segundo un artigo divulgativo que me mandou unha amiga norteamericana, ali a elección está limitada ás familias que xa teñen un fillo, para evitar que o primoxénito sexa sempre varón. Parece que esta preferencia é case xeral. Máis dun noventa por cento de parellas de todo o mundo prefiren un primeiro fillo varón ${ }^{4}$

O cohipónimo masculino, o termo intensivo, pode aparecer marcado mediante o substantivo varón, non sendo necesaria como é obvio un especificación deste tipo para a correspondente forma feminina, que só pode funcionar no nivel intensivo, segundo este esquema: fillo ${ }_{1} / /$ fillo varón / filla:

(6) (a) O meu primeiro fillo foi un neno ${ }_{2}$.

(b) $\mathrm{O}$ meu primeiro fillo, foi unha nena ${ }_{2}$.

Contrariamente, non son posíbeis enunciados como 'A miña primeira filla foi un neno', ou mesmo 'A miña primeira filla foi unha nena'. Este último enunciado é redundante, pois o substantivo filla posúe sempre o sema [+ femia], motivo polo cal se considera que o termo marcado da oposición en galego é aquel que posúe morfema de xénero feminino. Un procedimento similar utilízase ás veces para especificar o sexo naqueles nomes de persoa que apresentan sincretismo formal entre masculino e feminino, cando o contexto sintáctico en que habitualmente se substancia a expresión do morfema de xénero non axuda para o identificar:

(7) (a) Estivemos viaxando cun grupo de mulleres futbolistas.

(b) Estivemos viaxando cun grupo de futbolistas femininas.

(c) Estivemos viaxando cun grupo de homes futbolistas.

(d) Estivemos viaxando cun grupo de futbolistas masculinos.

Este caso debe ser interpretado de modo diverso que o de fillo, pois aquí sendo a forma extensiva a masculina (o futbolist $a_{1} / /$ o futbolista $a_{2}$ a futbolista), é máis

4 O DRAG (1998: s.v.) non recomenda o uso do substantivo varón en galego, e remete para home como única forma correcta. Pola súa parte, as dúas primeiras acepcións de home son as seguintes: "Animal da especie humana, a máis evolucionada da Terra, que se caracteriza fundamentalmente por adopta-la posición vertical, ter linguaxe articulada, intelixencia moi desenvolvida e facultade de razoar", e "Individuo da especie humana, de sexo masculino". No DAE (1994: s.v.) rexístrase unha forma varão con este último significado: "Indíviduo do sexo masculino", definición que coincide coa do DLP (1992: s.v.). 
habitualmente a feminina (a futbolista) a que precisa ser especificada (12a e 12b). A explicación corresponde non á semántica gramatical senón á semántica de uso, á pragmática, e ten a ver con fenómenos sociais como a incorporación da muller a todo o tipo de traballos e actividades antes realizadas unicamente por homes. Neste sentido, a lingua é un indicador das mudanzas que se producen na sociedade e do modo en que se desenvolven, ademais de transmitir contidos ideolóxicos e de exprimir en moitas ocasións a forma en que se articula o noso coñecimento e as nosas expectativas perante o mundo.

Outras veces este fenómeno vén causado por unha maior complexidade da estrutura semántica do xénero en determinados substantivos, dados os diferentes significados que poden adquirir os morfemas de xénero masculino e feminino. Desta maneira, no par opositivo o policía ${ }_{2} /$ a policía $a_{2}$ podemos distinguir dous termos hiperónimos opostos pola dimensión [ \pm abstracto]: o policía $a_{1}$ a policía onde o policía é o termo neutralizado que fai referencia á persoa sen distinguir o seu sexo ('Non apareceu nengún policía ${ }_{1}$ no momento do accidente'), e a policía designa o corpo de policía, a institución. Por iso ás veces faise necesario indicar mediante algún outro procedimento lexical, normalmente adxuntando o substantivo muller, que se está a falar no nivel ${ }_{2}$, facéndose referencia ao cohipónimo feminino, de acordo co seguinte esquema:

(8) (a) o policía $a_{1}$ os policías $\left.)_{1}\right) /$ a policía

(b) o policía $/$ a muller policía

Xeralmente, os nomes de profisións oferecen indicacións moi precisas sobre a realidade social, sendo diversas as solucións adoptadas para expresar as diferenzas sexuais. A terminación do substantivo é interpretada nalgunhas ocasións como se for un morfe xenérico, realizándose entón a flexión para o feminino mediante a conmutación da vogal polo sufixo - $a$ ou ben mediante o seu acrecentamento, pois o - $a$ foi considerado desde moi cedo como caracterizador do feminino: xuíza, avogada, decana, médica, enxeñeira, ministra, etc. ${ }^{5}$ :

(9) (a)

Pero certamente, é necesario acceder a todos os oficios e servicios técnicos que están reservados só aos homes. En lugar de secretaria, fontaneira, mecánica, albanela.

(Queizán, Voz, 22-11-99)

\footnotetext{
Os dicionarios e as normas lingüísticas non sempre recollen estas formas (que xa non son tan novas). Por outra parte, esta tendencia a marcar mediante un sufixo - $a$ a forma feminina está presente no idioma desde a Idade Media (de feito, ten a súa orixe no proprio latín: lupus/lupa), e explica resultados actuais como señora, portuguesa, etc. Ás veces unha realidade social nova pode causar certa inestabilidade no modo de expresar lingüisticamente o sexo dos referentes de determinados substantivos de oficio. Así, frente ao xa habitual substantivo feminino decana, temos escoitado nalgunha ocasión a un falante de idade avanzada utilizar a forma decano muller; noutras ocasións indícase o sexo mediante un morfema de xénero expreso só na concordancia e non nun morfe ligado ao lexema: o decano / a decano.
} 
(b)

A ministra de Meio Ambiente, Isabel Tocino, visitou Galiza o pasado Mércores 3 de Novembro

(ANT, 11-11-99)

\begin{abstract}
Noutros substantivos mantense unha certa inestabilidade nos usos (a cliente $\sim a$ clienta; a presidente $\sim$ a presidenta), se ben a tendencia é a de marcar sempre mediante o sufixo a forma feminina ${ }^{6}$. Na realidade, é esta unha posibilidade do sistema que se pode pór en práctica con diferentes motivacións ideolóxicas ou estilísticas, estiver ou non sancionado nun principio o seu uso pola norma, segundo a xa clásica distinción proposta por Coseriu (1981: 123-130)7 . O sistema lingüístico do galego permite distinguir sempre o xénero mediante sufixos ligados ao lexema, aínda que resulte pouco habitual e este procedimento non estexa fixado na norma, coas máis diversas intencións estilísticas: lúdicas, reivindicativas, etc. De tal maneira que é posíbel ouvir en determinados contextos comunicativos formas como membra, tipa (e mesmo macha), individua, etc ${ }^{8}$. Son causas extralingüísticas
\end{abstract}

* González Fernández (1978: 184-185), no entanto, afirma o seguinte ao respeito: "Además en las funciones de oficio, el masculino designa la función independiente a toda noción de sexo: catedrático, sirve de nombre de agente a la vez al hombre y a la mujer, pasando a ser término genérico. Para Dubois, el movimiento general que lleva en la actualidad a usar el masculino en los nombres de oficio tiene causas sociales, debido a la tendencia a suprimir las diferencias entre el trabajo del hombre y de la mujer. Esto repercute a la lengua, y aunque podemos decir catedrática, hay casos, como -al, -ante, -ista, que son el mismo sufijo para el masculino que para el femenino, y así se dice concellal, cantante, carteirista tanto para referirnos al hombre o a la mujer que tienen este oficio, y no *concellala, *cantanta, *carteiristo". Do noso ponto de vista, con estes últimos exemplos oférecese unha visión simplificada do que na realidade é máis complexo, pois, entre outras cousas, non dá conta de formas como clienta, presidenta, etc, habituais no galego de hoxe. Doutra parte, a afirmación sobre a tendencia a usar o masculino para os nomes de oficio e a súa explicación non parecen axeitadas para a realidade de uso actual, talvez por se basear en Dubois, cuxas argumentacións están referidas ao francés, lingua en que o funcionamento do xénero nestes casos é levemente diferente ao do galego.

7 "Como corolario, la norma es un conjunto formalizado de realizaciones tradicionales; abarca lo que ya "existe", lo que ya se ha realizado en la tradición lingüística. El sistema, por el contrario, es un conjunto de posibilidades de realización: abarca también lo que no se ha realizado aún, pero que es virtualmente existente, lo que es "posible", es decir, lo que puede ser creado de acuerdo con las reglas funcionales de la lengua" (Coseriu 1981: 126).

8 O uso masculino en formas habitualmente femininas, representado non apenas pola concordancia senón tamén polo morfe -o, pode ter ás veces unha intención estilística determinada, despectiva ou simplesmente paródica: ¿Con que ti eres un poetiso vergonzante? ¿De que rapaza eres muso? ¿Non reparaches nunca que tes un misterioso sorriso de Giocondo? (Fole, ALC 75). Véxase neste sentido tamén o adxectivo laverco/-a, criado a partir do substantivo feminino e invariábel canto ao xénero laverca, e que no entanto posúe flexión xenérica. Doutro lado, o sufixo -as utilizado para formar adxectivos depreciativos (conas, trolas, merdas...) pode supor unha caracterización mórfica feminina de nomes referidos a homes e de xénero masculino (que manteñen contodo o seu xénero: un conas, un trolas, un merdas). Este sufixo pode aparecer tamén asociado aos sufixos -allo (bardallas) e -ico (mexericas) (cfr. Ferreiro 1997: 145-146): ou o Setesaias, ou o Maricallas (Blanco Amor, OGC I 21 ). Por último, a reinterpretación mórfica das terminacións dos nomes está relacionada ás veces coa tendencia regularizadora da linguaxe infantil, que pretende facer todos os masculinos terminaren en -o e todos os femininos terminaren en $-a$. Neste sentido, temos presenciado unha situación en que unha cativa chamaba a un amigo da súa mesma idade idioto. 
as que determinan as especializacións de significado que acompañan en ocasións estas novas formas, así como a consideración depreciativa que poden adquirir. Así, por exemplo, non parece ser moi forte a tendencia a flexionar mediante un sufixo o substantivo estudante (estudanta), sendo a marca máis frecuente para o feminino o artigo correspondente ( $a$ estudante). A causa podería fundarse nun antigo matiz despectivo aplicado a este substantivo para designar nunha determinaba altura histórica as mulleres que ousaban estudar, e que nunha sociedade sexista e androcéntrica eran minoría, o cal inhibiría o seu uso co morfe proprio do feminino a favor dunha expresión xenérica exclusivamente sintáctica. Son tamén causas extralinguísticas as que explican a falta de simetría entre a forma masculina e a feminina no significado de determinados substantivos, que exemplificamos con apenas dúas oposicións que consideramos moi representativas:

(10) (a) asistente / asistenta

(b) modista / modisto

En (10a) temos unha forma feminina asistenta que designa habitualmente a persoa que realiza traballos domésticos, referida, obviamente, a mulleres, se ben a masculina fai referencia só ao home ou ben á persoa que asiste a un lugar ou que axuda nun determinado labor:

(11) (a) Os asistentes ao acto encheron o local

(b) As asistentes ao acto encheron o local

(c) *As asistentas ao acto encheron o local

A forma masculina plural de (11a) podería ser analisada como pertencente ao nivel ou ao nivel ${ }_{2}$, como termo intensivo ou como extensivo, entanto que a forma de (11b) só pode ser analisada no nivel da intensión e fai referencia exclusivamente a persoas do sexo feminino. A forma asistentas de (11c) posúe no entanto un significado diferente que non lle permite ser utilizado neste enunciado (coa especificación ao acto), pois significa 'muller que realiza traballos domésticos por conta allea' e é sinónimo de criadas e serventas. O feito de non funcionar este significado cando aplicada a homes é proba dunha realidade social discriminatoria, mais a desigualdade non se produce inicialmente no seo da lingua, que non constitúe máis do que un reflexo desa situación?

O caso de (10b) é sensibelmente diferente, pois é a partir da forma feminina, usada en primeiro lugar, que se criou unha forma masculina, trocando o - $a$ final, reinterpretado como morfe de xénero feminino, polo -o que representa morficamente o masculino. Mais nesta ocasión a forma masculina especializou o

9 O DRAG (1998: s.v.) inclúe a seguinte observación: "É infrecuente o uso do masculino cando se refire á persoa que realiza traballos domésticos". Seguramente, o que resulta realmente infrecuente é que un home realice tais traballos, de aí que non se use a forma masculina con esa acepción. 
seu significado cun uso diferente, pasando a ser sinónimo de deseñador (aplicado fundamentalmente a criadores de alta costura), entanto que a forma feminina, modista, continuou a ser empregada máis comunmente como sinónimo de costureira. Por ficar o substantivo feminino reservado para este uso, a muller que realiza deseños de roupa é denominada normalmente deseñadora e non modista, apesar de existir tamén esa posibilidade no sistema ${ }^{10}$. O que pon de manifesto tal desequilibrio nos significados dos termos flexionados dun mesmo substantivo (modista / modisto) é unha realidade socio-económica desigual no tocante á relación entre o sexo e a división do traballo na nosa sociedade. Outros nomes de profisións ou cargos que antigamente designaban na súa forma feminina a esposa dos homes que os exercían, van perdendo na actualidade este significado para facer referencia simplesmente á muller que realiza estas funcións (alcaldesa, sarxenta, capitá, etc). O feito de existiren formas femininas mesmo antes de haber mulleres que exercesen estas profisións ou cargos pon de manifesto, así mesmo, a rendibilidade do mecanismo flexional de xénero, que ten a posibilidade de adquirir os máis diversos significados lingüísticos, normalmente en relación coa distinción sexual (mais non só). A interpretación da terminación do substantivo como expresión mórfica de xénero existe, segundo estamos vendo, como unha posibilidade máis do sistema, podendo ser diversas as significacións -e sobretodo as connotacións- que encerre, de acordo coas necesidades comunicativas que se formen dentro da estrutura social en que son utilizadas en cada momento histórico.

Hai, aliás, outros factores que poden influír na utilización ou non dun sufixo específico para exprimir o xénero feminino dun substantivo no nivel da intensión, entre os cais debemos destacar a posíbel polisemia que resulta desas formas femininas cun sufixo $-a$. De todos os xeitos, a polisemia é un recurso moi estendido na nosa lingua, sen que noutras ocasións se produza calquer efeito de anulación dun dos significados dun determinado substantivo. Neste sentido, xa vimos ser perfeitamente asumida a polisemia da forma masculina nestes pares opositivos, sendo o contexto en que se insere o substantivo quen permite distinguir se está a ser utilizado no nivel intensivo ou no extensivo". Podemos supor, portanto, que son novamente causas extralingüísticas as que inhiben en ocasións o uso das formas femininas que debían ser normais, como mecánica, política, química, física, no nivel $\mathrm{l}_{2}$ (intensivo) da oposición, en favor de formas como a mecánico, a político, a químico, a físico.

${ }^{10}$ Por este motivo parece discutíbel a apreciación de Arias Barredo (1995: 51) sobre o carácter extensivo para o español do substantivo modista $a_{1}$, realizado no nivel intensivo da oposición sexual como modista $a_{2}+$ modisto. Véxase o que a este respeito afirma Nissen: "As a matter of fact, it represents an example of linguistic male dominance par excellence” (1986: 734-736).

1 Para Ullmann (1987: 347) a polisemia resulta un mecanismo económico e rendíbel mercé á influencia que exerce o contexto para clarificar o significado das palabras: "Como funciona na prática este delicado mecanismo? A principal garantia do seu funcionamento normal é a influência do contexto. Não interessa o número de significados que uma palabra possa ter no dicionário; não haverá confusão se apenas um deles fizer sentido numa dada situação". 
mundo segundo a distinción dos sexos, outras recorren a explicacións de tipo formal, defendendo unha posíbel extensión analóxica do sufixo feminino a determinados substantivos, o cal provocaría a aparición de todo un sistema de concordancias sobre a base de diferentes clases de nomes (cfr. Fodor 1959; Câmara 1974: 130-139; Gonçalves 1995). Por outra parte, existen diversos tipos de sistemas xenéricos nas linguas do mundo, e non todos eles se fundamentan en distincións de carácter semántico, pois algúns asignan o xénero aos nomes de acordo con criterios exclusivamente formais: fonolóxicos ou morfolóxicos (Corbett 1991: 7-68). E mesmo naqueles sistemas en que o significado do nome determina o seu xénero, son moi variadas as distincións semánticas que as clases de nomes poden reflectir (poden distinguir o comestíbel do non comestíbel, o que voa do que non voa, etc.), se ben son moi frecuentes aqueles que diferencian os seres segundo as oposicións animado / inanimado, humano / non-humano, macho / femia, seguramente por representaren estas oposicións fundamentais clasificacións da experiencia para calquer ser humano. De todas as maneiras, o que é común a todos estes sistemas, que xeralmente teñen un núcleo semántico, é a existencia de relacións de concordancia, único criterio que permite determinar o número de xéneros dunha lingua.

A frecuente existencia dun núcleo semántico, que segundo Corbett é fundamental para a asimilación de empréstimos e que Surridge (1993) considera importante no proceso de adquisición do sistema xenérico por parte dos neofalantes, ten suscitado, no entanto, interesantes consideracións sobre o modo en que esa clasificación da experiencia inflúe na percepción do mundo por parte dos falantes, e, desde posicións feministas, sobre cómo a división gramatical masculino / feminino, coincidente en parte coa distinción semántica macho / femia, pode supor a imposición dunha determinada cosmovisión particularmente androcéntrica. Un dos primeiros traballos que chamaron a atención sobre as posíbeis implicacións desta relación entre categoría gramatical e contido semántico foi o de Ervin (1962). Nel analísanse as connotacións que o xénero gramatical pode adquirir, mesmo en nomes que designan seres inanimados, do ponto de vista do sexo:

We may therefore expect to find three different bases for meaning which might be generalized: (a) sexual simbolism associated with anatomical difference or sexual relations; (b) physical properties varying in their correlation with sex, such as size; (c) cultural associations such as contrasts in beauty, slowness, laziness, and stability. Within a given culture, we can predict systematic contrasts in meaning between masculine and feminine words with no animate referent (p. 253).

Estas hipóteses deben ser postas en relación coas de Spitzer (1941), Hasselrot (1950) e Lapa (1984: 129) sobre a orixe da distinción xenérica en nomes de seres inanimados, cando a relación semántica entre os termos do par exprime diferenzas formais ou de tamaño nas linguas románicas. Nestes casos as explicacións son variadas e ás veces contraditorias, por responderen fundamentalmente a 
mundo segundo a distinción dos sexos, outras recorren a explicacións de tipo formal, defendendo unha posíbel extensión analóxica do sufixo feminino a determinados substantivos, o cal provocaría a aparición de todo un sistema de concordancias sobre a base de diferentes clases de nomes (cfr. Fodor 1959; Câmara 1974: 130-139; Gonçalves 1995). Por outra parte, existen diversos tipos de sistemas xenéricos nas linguas do mundo, e non todos eles se fundamentan en distincións de carácter semántico, pois algúns asignan o xénero aos nomes de acordo con criterios exclusivamente formais: fonolóxicos ou morfolóxicos (Corbett 1991: 7-68). E mesmo naqueles sistemas en que o significado do nome determina o seu xénero, son moi variadas as distincións semánticas que as clases de nomes poden reflectir (poden distinguir o comestíbel do non comestíbel, o que voa do que non voa, etc.), se ben son moi frecuentes aqueles que diferencian os seres segundo as oposicións animado / inanimado, humano / non-humano, macho / femia, seguramente por representaren estas oposicións fundamentais clasificacións da experiencia para calquer ser humano. De todas as maneiras, o que é común a todos estes sistemas, que xeralmente teñen un núcleo semántico, é a existencia de relacións de concordancia, único criterio que permite determinar o número de xéneros dunha lingua.

A frecuente existencia dun núcleo semántico, que segundo Corbett é fundamental para a asimilación de empréstimos e que Surridge (1993) considera importante no proceso de adquisición do sistema xenérico por parte dos neofalantes, ten suscitado, no entanto, interesantes consideracións sobre o modo en que esa clasificación da experiencia inflúe na percepción do mundo por parte dos falantes, e, desde posicións feministas, sobre cómo a división gramatical masculino / feminino, coincidente en parte coa distinción semántica macho / femia, pode supor a imposición dunha determinada cosmovisión particularmente androcéntrica. Un dos primeiros traballos que chamaron a atención sobre as posíbeis implicacións desta relación entre categoría gramatical e contido semántico foi o de Ervin (1962). Nel analísanse as connotacións que o xénero gramatical pode adquirir, mesmo en nomes que designan seres inanimados, do ponto de vista do sexo:

We may therefore expect to find three different bases for meaning which might be generalized: (a) sexual simbolism associated with anatomical difference or sexual relations; (b) physical properties varying in their correlation with sex, such as size; (c) cultural associations such as contrasts in beauty, slowness, laziness, and stability. Within a given culture, we can predict systematic contrasts in meaning between masculine and feminine words with no animate referent (p. 253).

Estas hipóteses deben ser postas en relación coas de Spitzer (1941), Hasselrot (1950) e Lapa (1984: 129) sobre a orixe da distinción xenérica en nomes de seres inanimados, cando a relación semántica entre os termos do par exprime diferenzas formais ou de tamaño nas linguas románicas. Nestes casos as explicacións son variadas e ás veces contraditorias, por responderen fundamentalmente a 
consideracións que teñen a ver coa propria visión do mundo destes autores, encadrada á súa vez nun contexto histórico e cultural determinado. Así, por exemplo, Hasselrot e Spitzer, ao explicaren a determinación semántica de cada un dos xéneros, relacionan o masculino co que é grande e forte, e o feminino co que resulta ser pequeno e débil, mais deben recorrer á comparación co corpo humano para explicaren o que denominan feminino aumentativo, aludindo ás redondezas do corpo da muller ou ao seu pretenso carácter vago, indeterminado, e á percepción da inmensidade do seu seo maternal. Lapa, pola súa parte, ve nesta suposta sexualización dos obxectos, representados como masculinos ou femininos, un dos caracteres principais da civilización portuguesa. O que revela tal variedade de argumentos é, polo que parece, a necesidade de buscar en cada caso unha explicación ad hoc, pois na realidade non é posíbel explicitar un número reducido de argumentos que den conta, por vía simbólica, de todos e cada un dos significados que estes pares de nomes co sema [- animado] poden adquirir ${ }^{13}$. Doutra parte, porén, as conclusións de Ervin poden ser válidas por canto desvelan as connotacións que os falantes atribúen a esta categoría linguística en determinados contextos dentro dunha cultura particular, mais, do noso ponto de vista, non serven para explicar a orixe da categoría nen son proba dun determinismo lingüístico que nos obrigue a perceber o mundo dun xeito específico. Entre outros motivos, porque a percepción simbólica do masculino e do feminino pode mudar dunha sociedade para outra ou inclusive, nun mesmo contexto social, dun momento histórico para outro ${ }^{14}$.

Máis recentemente Violi (1991), que ten abordado dun modo abranxente a cuestión do sexismo lingüístico, pergúntase sobre o carácter arbitrario ou simbólico da categoría de xénero gramatical. Esta autora, partindo de que no idioma nada é neutro, baséase en Sapir e na súa teoría sobre os dogmas do inconsciente para defender a existencia dun sistema semántico profundo, nacido dunha previa simbolización sexual do mundo. Desde esta perspectiva, ese sistema semántico é quen leva o falante a entender os xéneros como categorías naturais en que encadrar a súa experiencia da realidade, influíndo así na súa percepción e mesmo na súa propria estrutura psíquica. Unha proba dese simbolismo inicial perdido estaría na "disponibilidade metafórica" do xénero gramatical, que se manifesta por exemplo nos procesos retóricos de personificación de elementos como a terra, a auga, a morte, o sol ou a lúa en diferentes culturas. O sexo do ser que os representa correspóndese, segundo esta hipótese, co xénero dos substantivos que nomean estas realidades, provocando evidentes dificuldades na tradución de textos

1.3 Véxanse pares como pozo / poza ou río/ría, pois son diversas as explicacións simbólicas que se poden escoller para xustificar a súa relación semántica, con base na comparación co corpo humano ou non, dependendo exclusivamente da capacidade imaxinativa de cada un.

${ }^{14}$ Como afirma Alpher (1987: 185): "Rigorous demonstration that grammatical gender configurations affect people's thought patterns is, however, a more difficult problem, where testing is difficult or impossible, and where there is a danger of circularity". 
literarios dunhas linguas para outras. A este respeito, pensamos que a propria variedade que apresentan estes substantivos canto ao xénero nas diversas linguas pon en cuestión tal simbolismo profundo. Por outra parte, a capacidade simbólica do xénero está presente na posibilidade de ser relacionado co contido sexual, por causa da vinculación que nalgúns casos existe entre o nivel gramatical e o semántico (que estando relacionados non son equivalentes), mais non nos parece verosímil que articule en todo o momento a nosa percepción do mundo. Alén diso, os procesos de metaforización poden responder a condicionantes variados, sen teren a ver necesariamente coa relación entre xénero e sexo.

Violi acusa os lingüistas de ocultaren a diferenza sexual que se manifesta no idioma mercé a un proceso de inversión simbólica, e pon o acento na denuncia da redución do feminino, considerado sempre como termo negativo da oposición, como termo marcado e incapaz de expresar o xenérico, englobado no masculino que se apresenta como neutro, xenérico e non marcado. Pensamos que non se debe eludir esta cuestión nun estudo sobre o xénero gramatical, sobretodo se abordarmos o contido semántico que este morfema posúe cando serve para opor dous termos dun mesmo lexema, e tendo en conta que a inestabilidade dos usos lingüísticos a respeito do xénero e a súa diversa intencionalidade ideolóxica sitúan o tema no centro dun importante (e necesario) debate sobre discriminación e igualdade. Neste sentido, son comprensíbeis as suspeitas que unha análise formalista como a que propomos pode suscitar. A dupla face do morfema de xénero, cun significado gramatical e outro lexical, relacionados mais non equivalentes, permite explicar o funcionamento do sistema xenérico en galego: o masculino, como categoría gramatical, non englobaría o feminino, senón que expresaría a indiferenza á distinción sexual (en paralelo, portanto, tampouco o macho engloba a femia, pois nese masculino gramatical está ausente calquer sema que faga referencia ao sexo). A necesidade da utilización dun dos termos da oposición gramatical e semántica para servir como neutro vén marcada pola inexistencia dun terceiro termo extensivo, pois nalgunha ocasión é realmente necesario exprimir lingüisticamente a non diferenza sexual, sen existir calquer outra posibilidade para o facer. Sucede así no exemplo que propuxemos máis arriba (6b), 'O meu primeiro fillo foi unha nena', onde o que se pretende co uso do masculino é precisamente non adiantar unha información que se explicita a seguir, e tamén nos seguintes textos xornalísticos:

(12) (a)

O perfil do parado español é muller, de menos de 35 anos e con escasa preparación académica.

(Queizán, Voz 22-11-99)

(b)

Unha das máis vellas aspiracións da parella humana é a de poder escoller o sexo dos seus fillos.

(Mayoral, Voz 3-2-00) 
Nestes exemplos, porén, existe a posibilidade de fuxir do masculino extensivo. En (12a) afastando o adxectivo parado da función de núcleo do sintagma nominal e devolvéndoo á súa función modificadora orixinal, mediante a inclusión dun substantivo como persoa: 'O perfil da persoa parada española...'. En (12b) substituíndo o substantivo fillos, na súa forma plural masculina, extensiva, por outro substantivo de carácter abstracto en que estexa ausente a información sexual: '...poder escoller o sexo da descendencia'. Sobre estas propostas de uso falaremos máis adiante; agora chamamos a atención sobre un caso en que non existe, que saibamos, calquer outra alternativa para expresar lingüisticamente a non distinción de sexos: o do atributo de substantivos coordenados con diferentes xéneros gramaticais, que sempre posúe xénero masculino:

(13) A ladroa e o seu cúmplice foron detidos pola policía.

En ocasións, no entanto, son máis de dous os elementos coordenados ou xustapostos con diferente xénero; se ademais os nomes fan referencia a seres animados e o xénero gramatical exprime tamén o sexo dos referentes, moi especialmente se se trata de nomes proprios, pode surxir algunha dúbida sobre a forma xenérica a utilizar e sobre o carácter máis ou menos democrático da opción (no sentido de que se considera comunmente preferíbel a dominancia do maioritario). De todos os xeitos, o funcionamento lingüístico da concordancia e o carácter gramatical do xénero son os mesmos que no exemplo (13):

(14) (a) María, Luísa, Eva, Marta, Beatriz e Pedro son bons amigos.

(b) *María, Luísa, Eva, Marta, Beatriz e Pedro son boas amigas.

Alén diso, as formas pronominais invariábeis canto a xénero concordan sempre en masculino e singular, o cal vén apoiar a idea de que o masculino funciona realmente como forma da categoría gramatical do xénero non marcada semanticamente (de igual maneira que na categoría número é o singular a forma non marcada e o plural a marcada, neste caso mesmo morficamente), expresando a indeferenza á distinción sexual:

(15) (a) Iso que tes aí é branco.

(b) *Iso que tes aí son brancos.

(c) *Iso que tes aí é(son) branca(s).

(16) (a) Non hai ninguén atento á explicación.

(b) *Non hai ninguén atentos á explicación.

(c) ?Non hai ninguén atenta á explicación.

(d) *Non hai ninguén atentas á explicación.

(17) (a) Esperamos a chegada de alguén interesado nos nosos problemas.

(b) *Esperamos a chegada de alguén interesados nos nosos problemas.

(c) ?Esperamos a chegada de alguén interesada nos nosos problemas.

(d) *Esperamos a chegada de alguén interesadas nos nosos problemas. 
Na cláusula (16c) mantemos un interrogante por nos parecer posíbel a existencia dunha situación comunicativa en que se faga concordar o pronome cuantificador absoluto ninguén cun modificador feminino: alguén que fale diante dun auditorio composto unicamente por mulleres pode sentir a necesidade de facer un uso feminino deste pronome invariábel, dado o seu carácter referencial neste contexto. Tamén no exemplo (17c) é posíbel que se espere a chegada dunha muller e que se pretenda marcar iso especificamente. De todos os xeitos, o que caracteriza os pronomes invariábeis é o feito de concordaren en masculino e singular ${ }^{15}$. Doutra parte, nas cláusulas (16a) e (17a) os respectivos pronomes ninguén e alguén fan referencia a calquer persoa, sen especificar o seu sexo.

Véxase así mesmo a diferenza que existe entre atributos concertados e non concertados en exemplos como os seguintes:

(18) (a) - ¿Es $a$ alt $a$ ? -Non $a$ son.

(b) - ¿Es alt $a$ ? -Non $o$ son.

(c) - ¿Son as altas? -Non as son.

(d) - ¿Son altas? -Non $o$ son.

De maneira que se pode utilizar o pronome na súa forma feminina e plural (1 8a e 18c) cando ten un carácter identificador e fai referencia a unha ou varias mulleres, mais só se pode utilizar a forma masculina e singular cando o pronome non identifica senón que cualifica, por representar este termo precisamente o non marcado do ponto de vista do xénero e do número.

\subsection{A expresión do sexo e o sexismo linguiístico}

Apesar da necesidade, para nós evidente, de separarmos o que é unha categoría gramatical que funciona sen excepción en todos os nomes, posuíndo sempre un significado gramatical, do contido semántico de sexo que tal categoría pode adquirir nalgunhas ocasións, é preciso aínda perguntármonos pola causa de a neutralización da oposición semántica de sexo se producir no morfema masculino (ou no substantivo que designa o macho), e polas consecuencias que tal ambigüidade significativa ocasiona. Pois se ben as hipóteses formalistas sobre a orixe do xénero fundamentan a súa aparición na extensión analóxica dun

15 De igual modo, algúns procesos de transcategorización realízanse através de formas caracterizadas polo masculino e o singular, por ser esta a forma non marcada. Vemos isto en casos de substantivización: $\boldsymbol{o}$ falar; $\boldsymbol{o}$ si e o non, o antes e o despois, o adeus, un al go (cfr. Freixeiro Mato 1999: 253). Tamén a conversión dun adxectivo en adverbio se fai habitualmente através da forma masculina: Esta testemuña é meio parva. De todas as maneiras, pódense dar casos de flexión do adverbio, por atracción do adxectivo: meia parva; meios parvos, etc.: "Como ocurre en el castellano de América, en la comarca ferrolana el adjetivo medio con función adverbial concierta con el sustantivo en género y número. Así, Estaba media morta 'Estaba medio muerta', Sodes medios tolos 'Sois medio locos'" (Porto Dapena 1977: 153). 
sufixo feminino (que designaba a muller) a certos nomes, o cal oferece unha explicación para a expresión morfosintáctica do sexo e para o carácter intensivo do feminino, non existe nengunha argumentación similar que explique por qué é o substantivo que designa o macho, cando falamos de expresión lexemática do sexo, o extensivo. Doutra parte, nos nomes de animais ocasionalmente a femia funciona tamén no nivel da extensión, como termo neutro, dependendo da súa relevancia e utilidade para o conxunto dos falantes (galiña, cabra). Todo isto debe facernos reflectir, tal como puña de manifesto Patrizia Violi, sobre as implicacións que poida ter o facto de unha lingua determinada escoller para nomear todos os seres dunha especie, machos e femias, un dos dous termos disponíbeis. O par opositivo home / muller supón un dos exemplos máis claros das consecuencias (elucidador tamén, posibelmente, das causas) desta asimetría significativa producida pola ambigüidade semántica da forma que designa o macho da especie.

A historia da voz ingl. man foi submetida a unha análise exhaustiva na lingua inglesa desde unha perspectiva feminista, pois, ao non posuír este idioma sistema de xénero nos substantivos, é precisamente no uso do pronome, no léxico referido a oficios e mais no proprio substantivo man, onde se desvelan usos discriminatorios do ponto de vista do sexo ${ }^{16}$. Pola súa parte, Coseriu (1981) nas súas notas para unha semántica diacrónica estrutural utiliza o substantivo home para exemplificar as mudanzas que poden experimentar as oposicións lexicais:

El término no marcado de una oposición "compleja" (es decir, de varios términos) puede eliminar a uno de los términos marcados, como en el caso del cambio de la oposición latina homo // vir / femina en francés e italiano. En este caso, el rumano, el español y el portugués han conservado (o han reconstituido) la estructura semántica del latín, aunque con diferencias en la norma y, en parte, con nuevos significantes: rum. om // bărbat / femeie, esp. hombre // varón / mujer, port. homem // varão / mulher. En francés e italiano, en cambio, el término no marcado "homo" ha eliminado el término marcado "vir", de suerte que significa tanto "hombre (en general)" como "hombre (por oposición a mujer)" (pp. 70-71)

Apesar de ser posíbel manter en español e galego-portugués esa oposición baseada na distinción sexual mediante dous termos intensivos sen ser nengún deles utilizado como hiperónimo, o certo é que esa antiga forma neutra, home, hoxe se identifica máis comunmente co significado de varón, polo que se queremos

16 Véxase Bodine (1975), quen fai un resumo das alternativas propostas para utilizar un inglés non sexista, tais como a criación de pronomes "epicenos". Baron (1986: 27-54), ademais desta cuestión dos pronomes, centra o seu estudo no diferente uso que fan da lingua homes e mulleres, nas relación entre o sexo dos interlocutores e as pautas conversacionais, etc. 
mundo segundo a distinción dos sexos, outras recorren a explicacións de tipo formal, defendendo unha posíbel extensión analóxica do sufixo feminino a determinados substantivos, o cal provocaría a aparición de todo un sistema de concordancias sobre a base de diferentes clases de nomes (cfr. Fodor 1959; Câmara 1974: 130-139; Gonçalves 1995). Por outra parte, existen diversos tipos de sistemas xenéricos nas linguas do mundo, e non todos eles se fundamentan en distincións de carácter semántico, pois algúns asignan o xénero aos nomes de acordo con criterios exclusivamente formais: fonolóxicos ou morfolóxicos (Corbett 1991: 7-68). E mesmo naqueles sistemas en que o significado do nome determina o seu xénero, son moi variadas as distincións semánticas que as clases de nomes poden reflectir (poden distinguir o comestíbel do non comestíbel, o que voa do que non voa, etc.), se ben son moi frecuentes aqueles que diferencian os seres segundo as oposicións animado / inanimado, humano / non-humano, macho / femia, seguramente por representaren estas oposicións fundamentais clasificacións da experiencia para calquer ser humano. De todas as maneiras, o que é común a todos estes sistemas, que xeralmente teñen un núcleo semántico, é a existencia de relacións de concordancia, único criterio que permite determinar o número de xéneros dunha lingua.

A frecuente existencia dun núcleo semántico, que segundo Corbett é fundamental para a asimilación de empréstimos e que Surridge (1993) considera importante no proceso de adquisición do sistema xenérico por parte dos neofalantes, ten suscitado, no entanto, interesantes consideracións sobre o modo en que esa clasificación da experiencia inflúe na percepción do mundo por parte dos falantes, e, desde posicións feministas, sobre cómo a división gramatical masculino / feminino, coincidente en parte coa distinción semántica macho / femia, pode supor a imposición dunha determinada cosmovisión particularmente androcéntrica. Un dos primeiros traballos que chamaron a atención sobre as posíbeis implicacións desta relación entre categoría gramatical e contido semántico foi o de Ervin (1962). Nel analísanse as connotacións que o xénero gramatical pode adquirir, mesmo en nomes que designan seres inanimados, do ponto de vista do sexo:

We may therefore expect to find three different bases for meaning which might be generalized: (a) sexual simbolism associated with anatomical difference or sexual relations; (b) physical properties varying in their correlation with sex, such as size; (c) cultural associations such as contrasts in beauty, slowness, laziness, and stability. Within a given culture, we can predict systematic contrasts in meaning between masculine and feminine words with no animate referent (p. 253).

Estas hipóteses deben ser postas en relación coas de Spitzer (1941), Hasselrot (1950) e Lapa (1984: 129) sobre a orixe da distinción xenérica en nomes de seres inanimados, cando a relación semántica entre os termos do par exprime diferenzas formais ou de tamaño nas linguas románicas. Nestes casos as explicacións son variadas e ás veces contraditorias, por responderen fundamentalmente a 
consideracións que teñen a ver coa propria visión do mundo destes autores, encadrada á súa vez nun contexto histórico e cultural determinado. Así, por exemplo, Hasselrot e Spitzer, ao explicaren a determinación semántica de cada un dos xéneros, relacionan o masculino co que é grande e forte, e o feminino co que resulta ser pequeno e débil, mais deben recorrer á comparación co corpo humano para explicaren o que denominan feminino aumentativo, aludindo ás redondezas do corpo da muller ou ao seu pretenso carácter vago, indeterminado, e á percepción da inmensidade do seu seo maternal. Lapa, pola súa parte, ve nesta suposta sexualización dos obxectos, representados como masculinos ou femininos, un dos caracteres principais da civilización portuguesa. O que revela tal variedade de argumentos é, polo que parece, a necesidade de buscar en cada caso unha explicación ad hoc, pois na realidade non é posíbel explicitar un número reducido de argumentos que den conta, por vía simbólica, de todos e cada un dos significados que estes pares de nomes co sema [- animado] poden adquirir ${ }^{13}$. Doutra parte, porén, as conclusións de Ervin poden ser válidas por canto desvelan as connotacións que os falantes atribúen a esta categoría linguística en determinados contextos dentro dunha cultura particular, mais, do noso ponto de vista, non serven para explicar a orixe da categoría nen son proba dun determinismo lingüístico que nos obrigue a perceber o mundo dun xeito específico. Entre outros motivos, porque a percepción simbólica do masculino e do feminino pode mudar dunha sociedade para outra ou inclusive, nun mesmo contexto social, dun momento histórico para outro ${ }^{14}$.

Máis recentemente Violi (1991), que ten abordado dun modo abranxente a cuestión do sexismo lingüístico, pergúntase sobre o carácter arbitrario ou simbólico da categoría de xénero gramatical. Esta autora, partindo de que no idioma nada é neutro, baséase en Sapir e na súa teoría sobre os dogmas do inconsciente para defender a existencia dun sistema semántico profundo, nacido dunha previa simbolización sexual do mundo. Desde esta perspectiva, ese sistema semántico é quen leva o falante a entender os xéneros como categorías naturais en que encadrar a súa experiencia da realidade, influíndo así na súa percepción e mesmo na súa propria estrutura psíquica. Unha proba dese simbolismo inicial perdido estaría na "disponibilidade metafórica" do xénero gramatical, que se manifesta por exemplo nos procesos retóricos de personificación de elementos como a terra, a auga, a morte, o sol ou a lúa en diferentes culturas. O sexo do ser que os representa correspóndese, segundo esta hipótese, co xénero dos substantivos que nomean estas realidades, provocando evidentes dificuldades na tradución de textos

1.3 Véxanse pares como pozo / poza ou río/ría, pois son diversas as explicacións simbólicas que se poden escoller para xustificar a súa relación semántica, con base na comparación co corpo humano ou non, dependendo exclusivamente da capacidade imaxinativa de cada un.

${ }^{14}$ Como afirma Alpher (1987: 185): "Rigorous demonstration that grammatical gender configurations affect people's thought patterns is, however, a more difficult problem, where testing is difficult or impossible, and where there is a danger of circularity". 
literarios dunhas linguas para outras. A este respeito, pensamos que a propria variedade que apresentan estes substantivos canto ao xénero nas diversas linguas pon en cuestión tal simbolismo profundo. Por outra parte, a capacidade simbólica do xénero está presente na posibilidade de ser relacionado co contido sexual, por causa da vinculación que nalgúns casos existe entre o nivel gramatical e o semántico (que estando relacionados non son equivalentes), mais non nos parece verosímil que articule en todo o momento a nosa percepción do mundo. Alén diso, os procesos de metaforización poden responder a condicionantes variados, sen teren a ver necesariamente coa relación entre xénero e sexo.

Violi acusa os lingüistas de ocultaren a diferenza sexual que se manifesta no idioma mercé a un proceso de inversión simbólica, e pon o acento na denuncia da redución do feminino, considerado sempre como termo negativo da oposición, como termo marcado e incapaz de expresar o xenérico, englobado no masculino que se apresenta como neutro, xenérico e non marcado. Pensamos que non se debe eludir esta cuestión nun estudo sobre o xénero gramatical, sobretodo se abordarmos o contido semántico que este morfema posúe cando serve para opor dous termos dun mesmo lexema, e tendo en conta que a inestabilidade dos usos lingüísticos a respeito do xénero e a súa diversa intencionalidade ideolóxica sitúan o tema no centro dun importante (e necesario) debate sobre discriminación e igualdade. Neste sentido, son comprensíbeis as suspeitas que unha análise formalista como a que propomos pode suscitar. A dupla face do morfema de xénero, cun significado gramatical e outro lexical, relacionados mais non equivalentes, permite explicar o funcionamento do sistema xenérico en galego: o masculino, como categoría gramatical, non englobaría o feminino, senón que expresaría a indiferenza á distinción sexual (en paralelo, portanto, tampouco o macho engloba a femia, pois nese masculino gramatical está ausente calquer sema que faga referencia ao sexo). A necesidade da utilización dun dos termos da oposición gramatical e semántica para servir como neutro vén marcada pola inexistencia dun terceiro termo extensivo, pois nalgunha ocasión é realmente necesario exprimir lingüisticamente a non diferenza sexual, sen existir calquer outra posibilidade para o facer. Sucede así no exemplo que propuxemos máis arriba (6b), 'O meu primeiro fillo foi unha nena', onde o que se pretende co uso do masculino é precisamente non adiantar unha información que se explicita a seguir, e tamén nos seguintes textos xornalísticos:

(12) (a)

O perfil do parado español é muller, de menos de 35 anos e con escasa preparación académica.

(Queizán, Voz 22-11-99)

(b)

Unha das máis vellas aspiracións da parella humana é a de poder escoller o sexo dos seus fillos.

(Mayoral, Voz 3-2-00) 
Nestes exemplos, porén, existe a posibilidade de fuxir do masculino extensivo. En (12a) afastando o adxectivo parado da función de núcleo do sintagma nominal e devolvéndoo á súa función modificadora orixinal, mediante a inclusión dun substantivo como persoa: 'O perfil da persoa parada española...'. En (12b) substituíndo o substantivo fillos, na súa forma plural masculina, extensiva, por outro substantivo de carácter abstracto en que estexa ausente a información sexual: '...poder escoller o sexo da descendencia'. Sobre estas propostas de uso falaremos máis adiante; agora chamamos a atención sobre un caso en que non existe, que saibamos, calquer outra alternativa para expresar lingüisticamente a non distinción de sexos: o do atributo de substantivos coordenados con diferentes xéneros gramaticais, que sempre posúe xénero masculino:

(13) A ladroa e o seu cúmplice foron detidos pola policía.

En ocasións, no entanto, son máis de dous os elementos coordenados ou xustapostos con diferente xénero; se ademais os nomes fan referencia a seres animados e o xénero gramatical exprime tamén o sexo dos referentes, moi especialmente se se trata de nomes proprios, pode surxir algunha dúbida sobre a forma xenérica a utilizar e sobre o carácter máis ou menos democrático da opción (no sentido de que se considera comunmente preferíbel a dominancia do maioritario). De todos os xeitos, o funcionamento lingüístico da concordancia e o carácter gramatical do xénero son os mesmos que no exemplo (13):

(14) (a) María, Luísa, Eva, Marta, Beatriz e Pedro son bons amigos.

(b) *María, Luísa, Eva, Marta, Beatriz e Pedro son boas amigas.

Alén diso, as formas pronominais invariábeis canto a xénero concordan sempre en masculino e singular, o cal vén apoiar a idea de que o masculino funciona realmente como forma da categoría gramatical do xénero non marcada semanticamente (de igual maneira que na categoría número é o singular a forma non marcada e o plural a marcada, neste caso mesmo morficamente), expresando a indeferenza á distinción sexual:

(15) (a) Iso que tes aí é branco.

(b) *Iso que tes aí son brancos.

(c) *Iso que tes aí é(son) branca(s).

(16) (a) Non hai ninguén atento á explicación.

(b) *Non hai ninguén atentos á explicación.

(c) ?Non hai ninguén atenta á explicación.

(d) *Non hai ninguén atentas á explicación.

(17) (a) Esperamos a chegada de alguén interesado nos nosos problemas.

(b) *Esperamos a chegada de alguén interesados nos nosos problemas.

(c) ?Esperamos a chegada de alguén interesada nos nosos problemas.

(d) *Esperamos a chegada de alguén interesadas nos nosos problemas. 
Na cláusula (16c) mantemos un interrogante por nos parecer posíbel a existencia dunha situación comunicativa en que se faga concordar o pronome cuantificador absoluto ninguén cun modificador feminino: alguén que fale diante dun auditorio composto unicamente por mulleres pode sentir a necesidade de facer un uso feminino deste pronome invariábel, dado o seu carácter referencial neste contexto. Tamén no exemplo (17c) é posíbel que se espere a chegada dunha muller e que se pretenda marcar iso especificamente. De todos os xeitos, o que caracteriza os pronomes invariábeis é o feito de concordaren en masculino e singular ${ }^{15}$. Doutra parte, nas cláusulas (16a) e (17a) os respectivos pronomes ninguén e alguén fan referencia a calquer persoa, sen especificar o seu sexo.

Véxase así mesmo a diferenza que existe entre atributos concertados e non concertados en exemplos como os seguintes:

(18) (a) - ¿Es $a$ alt $a$ ? -Non $a$ son.

(b) - ¿Es alt $a$ ? -Non $o$ son.

(c) - ¿Son as altas? -Non as son.

(d) - ¿Son altas? -Non $o$ son.

De maneira que se pode utilizar o pronome na súa forma feminina e plural (18a e 18c) cando ten un carácter identificador e fai referencia a unha ou varias mulleres, mais só se pode utilizar a forma masculina e singular cando o pronome non identifica senón que cualifica, por representar este termo precisamente o non marcado do ponto de vista do xénero e do número.

\subsection{A expresión do sexo e o sexismo linguiístico}

Apesar da necesidade, para nós evidente, de separarmos o que é unha categoría gramatical que funciona sen excepción en todos os nomes, posuíndo sempre un significado gramatical, do contido semántico de sexo que tal categoría pode adquirir nalgunhas ocasións, é preciso aínda perguntármonos pola causa de a neutralización da oposición semántica de sexo se producir no morfema masculino (ou no substantivo que designa o macho), e polas consecuencias que tal ambigüidade significativa ocasiona. Pois se ben as hipóteses formalistas sobre a orixe do xénero fundamentan a súa aparición na extensión analóxica dun

15 De igual modo, algúns procesos de transcategorización realízanse através de formas caracterizadas polo masculino e o singular, por ser esta a forma non marcada. Vemos isto en casos de substantivización: $\boldsymbol{o}$ falar; $\boldsymbol{o}$ si e o non, o antes e o despois, o adeus, un al go (cfr. Freixeiro Mato 1999: 253). Tamén a conversión dun adxectivo en adverbio se fai habitualmente através da forma masculina: Esta testemuña é meio parva. De todas as maneiras, pódense dar casos de flexión do adverbio, por atracción do adxectivo: meia parva; meios parvos, etc.: "Como ocurre en el castellano de América, en la comarca ferrolana el adjetivo medio con función adverbial concierta con el sustantivo en género y número. Así, Estaba media morta 'Estaba medio muerta', Sodes medios tolos 'Sois medio locos'" (Porto Dapena 1977: 153). 
sufixo feminino (que designaba a muller) a certos nomes, o cal oferece unha explicación para a expresión morfosintáctica do sexo e para o carácter intensivo do feminino, non existe nengunha argumentación similar que explique por qué é o substantivo que designa o macho, cando falamos de expresión lexemática do sexo, o extensivo. Doutra parte, nos nomes de animais ocasionalmente a femia funciona tamén no nivel da extensión, como termo neutro, dependendo da súa relevancia e utilidade para o conxunto dos falantes (galiña, cabra). Todo isto debe facernos reflectir, tal como puña de manifesto Patrizia Violi, sobre as implicacións que poida ter o facto de unha lingua determinada escoller para nomear todos os seres dunha especie, machos e femias, un dos dous termos disponíbeis. O par opositivo home / muller supón un dos exemplos máis claros das consecuencias (elucidador tamén, posibelmente, das causas) desta asimetría significativa producida pola ambigüidade semántica da forma que designa o macho da especie.

A historia da voz ingl. man foi submetida a unha análise exhaustiva na lingua inglesa desde unha perspectiva feminista, pois, ao non posuír este idioma sistema de xénero nos substantivos, é precisamente no uso do pronome, no léxico referido a oficios e mais no proprio substantivo man, onde se desvelan usos discriminatorios do ponto de vista do sexo ${ }^{16}$. Pola súa parte, Coseriu (1981) nas súas notas para unha semántica diacrónica estrutural utiliza o substantivo home para exemplificar as mudanzas que poden experimentar as oposicións lexicais:

El término no marcado de una oposición "compleja" (es decir, de varios términos) puede eliminar a uno de los términos marcados, como en el caso del cambio de la oposición latina homo // vir / femina en francés e italiano. En este caso, el rumano, el español y el portugués han conservado (o han reconstituido) la estructura semántica del latín, aunque con diferencias en la norma y, en parte, con nuevos significantes: rum. om // bărbat / femeie, esp. hombre // varón / mujer, port. homem // varão / mulher. En francés e italiano, en cambio, el término no marcado "homo" ha eliminado el término marcado "vir", de suerte que significa tanto "hombre (en general)" como "hombre (por oposición a mujer)" (pp. 70-71)

Apesar de ser posíbel manter en español e galego-portugués esa oposición baseada na distinción sexual mediante dous termos intensivos sen ser nengún deles utilizado como hiperónimo, o certo é que esa antiga forma neutra, home, hoxe se identifica máis comunmente co significado de varón, polo que se queremos

16 Véxase Bodine (1975), quen fai un resumo das alternativas propostas para utilizar un inglés non sexista, tais como a criación de pronomes "epicenos". Baron (1986: 27-54), ademais desta cuestión dos pronomes, centra o seu estudo no diferente uso que fan da lingua homes e mulleres, nas relación entre o sexo dos interlocutores e as pautas conversacionais, etc. 
desfacer a ambigüidade debemos recorrer para expresar o termo extensivo a formas como persoa, individuo, ser humano, tal como acontece en francés e italiano ${ }^{17}$.

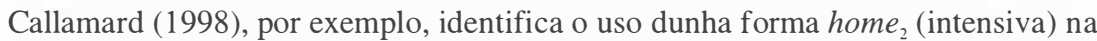
chamada declaración dos direitos do Home e o Cidadán aprobada o 26 de agosto de 1789. Para todos os participantes na Asemblea Nacional ficaba claro que este substantivo facía referencia exclusivamente aos varóns, malia participaren tamén activamente as mulleres no proceso revolucionario, pois as francesas tiveron de esperar até o ano 1944 para conseguiren o direito a voto e portanto a consideración de cidadás. Por este motivo, en 1791 Olympe de Gouges redactaba unha paralela declaración de direitos da Muller e da Cidadá e en xuño de 1993 unha conferencia internacional organizada pola ONU recomendaba substituír a expresión "direitos do home", utilizada aínda na declaración de 1948, por "direitos humanos". Agnes Callamard sitúa aquí a orixe desa utilización intensiva do substantivo home, auspiciada pola recomendación dos gramáticos franceses en favor do uso do masculino como forma neutra. Esta autora considera, finalmente, non ser frecuente este uso en textos franceses medievais, que expresaban a totalidade das persoas nomeando cada un dos sexos.

No que di respeito ao galego-portugués medieval, son tamén moi habituais as expresións que implican os dous termos do par opositivo, homes e mulleres, aínda que, ao contrario do que podería parecer nun primeiro momento, este uso ten a ver precisamente cunha explícita visión androcéntrica do acontecer humano. Polo que podemos enxergar nunha aproximación aos textos en prosa, o varón é considerado para os autores medievais como o único suxeito da historia, pois as mulleres son mencionadas apenas cando é preciso desde unha perspectiva informativa ou de expresión, en moitas ocasións en contextos carregados de connotacións negativas. Isto é o que acontece na General Estoria, que comeza relatando os albores da humanidade cun texto que pon de relevo ser só a historia dos homes, a que está a ser contada. Este uso intensivo do substantivo dedúcese mercé ao contexto lingüístico, isto é, mediante o contraste léxico con outros elementos do enunciado; neste caso faise evidente ao aparecer citado máis adiante o substantivo mulleres no mesmo parágrafo ${ }^{18}$. É portanto posíbel pensarmos que a mudanza no significado do substantivo home, de 'ser humano' a 'ser humano varón', tivese a súa orixe na

${ }^{17}$ Campos / Xavier (1991: 220) realizan a seguinte observación a este respeito: "Na constante evolução das línguas naturais, há expressões que nascem, outras que desaparecem ou se modificam, e a organização relativa das expressões que coexistem num dado estado de língua é continuamente feita e refeita. Por exemplo, na passagem do latim ao português, desapareceu o substantivo latino vir ("ser humano do sexo masculino"), e o seu sentido foi absorvido por outro substantivo latino home ("ser humano"). O substantivo homem surge assim, no léxico do português, acumulando aqueles dois sentidos".

18 Vila Pujol (1989: 317-318) afirma que o substantivo home actúa dun xeito particular en español, distinguíndose dos outros que poden expresar lexematicamente o sexo, pois nel o trazo [- femia] actualízase sempre que se particulariza e neutralízase cando se xeneraliza. 
inmediata identificación entre varón e 'ser humano' propria dunha sociedade sexista ${ }^{19}$ :

(19) (a)

Primeiramẽte os omẽ $s_{2}$ ñ̃ criiam em Deus, nẽ titnã creença nẽgũa, nẽ oravã a Deus, nẽ a outra cousa, nẽ aviam molleres apartadas, nẽ catavã nẽ davã nada por aver fillos conosçudos, nẽ casavã.

$(G E, 19)$

(b)

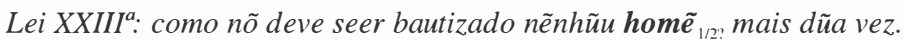

$(P P 153 b)$

(c)

Lei XXXIII: quaes ssom os pecados e quaes meores que os homẽ $s_{2}$ fazem e as molleres.

Véxase, ademais, cómo o termo home extensivo se utiliza para descreber o ritual do bautismo, entanto que a inclusión das mulleres parécelle necesaria ao autor cando se trata de facer unha enumeración de pecados. Tamén cando o contido semántico do sexo se exprime através dun morfema gramatical de xénero o sexismo lingüístico reside na utilización da forma masculina intensiva, por se considerar relevante apenas o termo co sema [- femia]. Este uso do termo hipónimo masculino explica a mención explícita ás mulleres (que non sería necesaria se o termo masculino utilizado fose o hiperónimo), o cal demostra que a simples expresión do par opositivo non permite atribuír a un texto sen máis a etiqueta de non sexista:

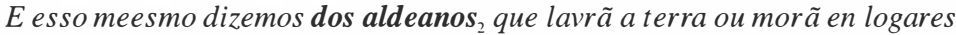
hu nõ ha pobrado e dos pastores ${ }_{2}$ que andã cõ os gaados ẽnos mõtes hermos ou das molheres que morassem ẽ taaes logares come estes.

(PP 153)

Doutra parte, as construcións bimembres de varios tipos facían parte do 'estilo' medieval, polo que non nos parece axeitado deducir deste uso, común ás linguas

19 Para Spender (1979: 23) o sexismo lingiiístico está relacionado co dominio da perspectiva do home (macho da especie humana) na produción cultural, o cal ten feito prevalecer o seu discurso: "The evidence for the relationship between sexism and language, and males, has been largely circumstantial: there is sexism in the language, it does enhance the position of males, and males have had control over the production of cultural forms. It therefore seems credible to assume that males have encoded sexism into the language to consolidate their claims of male supremacy". 
romances, unha vontade non discriminatoria ${ }^{20}$. O recurso a este tipo de construcións co par opositivo responde normalmente a causas pragmáticas, informativas, motivadas precisamente polo feito de o substantivo home non facer referencia tamén ás mulleres na maioría das ocasións:

(21) (a)

E mãdou que escrevessem os nomes de todos os que hi veessen pobrar, asi

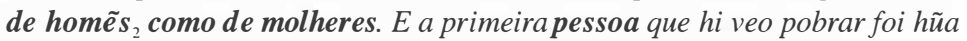
molher que avia nome Crunha

$(C G E 1344,94)$

(b)

Et para o asi mellor teermos, conpriremos $e$ atendermos, pagaremos $e$ guardarmos e contra elo nin parte dela non irmos nin pasarmos nin outros por nos, renunciamos e partimos de nos e de cada huuns de nos e das ditas çibdades e lugares por que fazemos todas las leis e dereitos, foros, usos e costumes, escriptos e non escriptos, canonicos e cebiis, raiaes e imperiaes e municipaes e estatutos e ordenamentos e libertades e toda carta e merçed de rei et reina e infante e duque e de outro señor ${ }_{2}$ ou señora, maior ou menor ou igual, destos erdeiro, ou çibdade, vila ou lugar e toda oste ou armada en todo lugar, coutado, sagrado et privilegiado, e a lei do engano, força, medo e temor.

$(L C P, 184)$

(c)

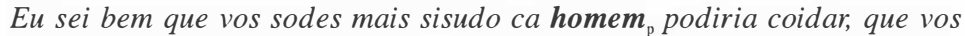
sabedes o que homem, nem molher nom podiria saber fora eи e meu irmão

(Demanda, 418)

Neste último fragmento (21c) o primeiro homem é un pronome cuantificador absoluto con valor impersoal (representamos este carácter pronominal co $p$ en subíndice). Podemos considerar tal función, igualmente, como unha extensión dese uso sexista que estamos a analisar, pois podería terse orixinado a partir de contextos lingüísticos como este que reproducimos a seguir, onde é difícil discernir o carácter nominal ou pronominal de homen:

(22) Nem entendemos que oje aja no mundo homen $\boldsymbol{p}_{\mathrm{p} \text { ? }}$ que o saibha

(CGE 1344, 101)

${ }^{20}$ González Ollé (1981) explica este fenómeno en español servíndose das teses dun traballo anterior de Smith: "Dicho estudioso aplica la denominación de parejas inclusivas a fórmulas "del tipo grandes e chicos, yermo e poblado, tan numerosas en los textos medievales", cuya intención "es la de mencionar dos términos que, siendo contrarios o extremos han de abarcar toda una extensión de puntos intermedios y comunicar la noción de una totalidad", y cuya popularidad, se debe, en su opinión, "a la necesidad que sentía la mentalidad medieval de expresar las grandes abstracciones y los conceptos vagos en términos concretos, individualizados, por la necesidad de asegurarse que estaba incluido "todo"". 
Finalmente, nestes textos medievais a identificación do masculino, ou da voz que designa o macho da especie, co xenérico e indiferenciado vai acompañada dunha identificación total entre xénero gramatical e sexo, como se pode apreciar no seguinte fragmento, que seguramente non respeita a concordancia en feminino por relacionar o seu autor de forma inconsciente 'persoa' con 'home':

En este dito dia e ora e por estas testimoias, ordenaron os ditos rejedores e alcaldes e procurador que persona nenhua non fose achado de andar por la dita çidade despois da canpaa tangida d'anunço

$$
\text { (LCP, 179) }
$$

Estes exemplos da lingua medieval constitúen o máis claro precedente da pasaxe que ás veces se produce no galego actual de home $e_{2}$ a home, nun mesmo enunciado, constituíndo máis unha proba dos mecanismos androcéntricos de identificación entre 'ser humano' e 'varón' arraigados na nosa mentalidade (nalgúns casos, moi probabelmente, de modo inconsciente). Talvez por iso a neutralización semántica nestes substantivos que expresan lexematicamente o sexo se produce, como dicíamos anteriormente, con máis facilidade no plural do que no singular, onde a ambiguiidade se mantén dun modo máis pertinaz, sen o contexto permitir elucidar en moitas ocasións se o termo está a ser utilizado no nivel da intensión ou no da extensión:

$$
1
$$

Un home 2:? $_{2}$ saí fuxindo da cidá en chamas e colleu o camiño dos outeiros, nas aforas, onde estaban os pazos dos poderosos

$$
\text { [...] }
$$

2

Polo carreiro que se perdía na negrura

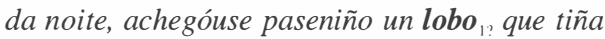

o don da fala humá, como seica pasaba nos tempos

milenarios do comenzo do mundo.

E chamóulle: irmáu home ${ }_{1}$.

(C. E. Ferreiro, OC I 174)

Neste poema de contido pacifista de Celso Emilio Ferreiro a primeira vez que aparece a voz home semella estar sendo utilizada no nivel ${ }_{2}$, como termo intensivo, encanto no segundo fragmento este substantivo designa toda a especie humana, en oposición a $l o b o_{1}$. A posibilidade de pasar dun nivel de significado a outro é favorecida pola ambigüidade semántica do substantivo, constituíndo un proceso psicolingüístico de claras consecuencias sexistas. Neste sentido, o movimento feminista ten insistido na necesidade de evitarmos usos ambigüos que favorecen a identificación entre 'home-varón' e 'xénero humano'. De calquer maneira, o 
sexismo dos textos medievais analisados anteriormente reside en referir toda a especie tendo en consideración unicamente o macho, e non na utilización da forma que designa o macho como hiperónimo.

En definitiva, pódese concluír que o uso extensivo do termo que designa o macho da especie, a neutralización semántica, foi causado por unha anterior utilización do termo intensivo como globalizador, en contextos socioculturais en que se fai cumprir á muller un papel secundario, subordinado a respeito do home. Por este motivo, aínda hoxe a preminencia do sema [- femia] neste tipo de substantivos ocasiona frecuentemente a inhibición do seu uso como hiperónimo, sobretodo no singular. Este é o caso de pai, padriño, etc., que adoitan utilizarse no nivel da hiperonimia preferentemente no plural, onde ao non existir un terceiro termo extensivo o galego non permite nengunha outra opción (excepto a repetición dos dous termos intensivos, se o plural non fai referencia a un conxunto maior). Así pois, na procura da máis esmerada claridade expositiva e para non favorecer identificacións discriminatorias no receptor é preferíbel evitar este tipo de enunciados ambigüos, tal como se fai neste texto de Ánxel Fole:

Máis de duascentas persoas estaban berrando a pé dun freixo moi outo. Todas ollaban ó cimo. Eu ouvía berrar a homes $i$-a mulleres

$$
\text { (Fole, ALC 25) }
$$

Véxase ademais cómo coa concordancia en feminino de todas fica clara a distinción entre xénero e sexo, pois só se pode explicar como un preconceito do receptor considerar imposíbel que nun enunciado como Todas ollaban ó cimo tamén se faga referencia a homes (os homes fican incluídos nesa forma feminina por referir anaforicamente ao substantivo feminino persoas). Por este motivo, sexa cal for a orixe destas neutralizacións, é necesario do noso ponto de vista distinguirmos entre o que é expresión lexemática de sexo e expresión morfosintáctica, isto é, entre a neutralización que se realiza co lexema que designa o macho (ou a femia) da especie e a que se produce no morfema de xénero masculino. Pois non podemos esquecer que o morfema de xénero posúe dúas faces, sendo fundamentalmente un morfema gramatical que adquire un contido semántico no nivel intensivo de determinadas oposicións (e ás veces tamén no extensivo), mais sen perder en nengún caso o seu significado gramatical ${ }^{21}$.

${ }^{21}$ García Meseguer (1994: 130) para facer explícita a distinción entre a hiperonimia das oposicións lexemáticas de sexo e a neutralización que se produce en favor do xénero masculino, distingue entre terno "dominado" e termo "marcado", mediante o seguinte exemplo: Zúnganos y abe jas son molestos, onde "el término zánganos es no marcado por ser de género m, pero es dominado (la palabra zángano es de significado específico y no incluye a la hembra). En tanto que abe jas es marcado por ser f (la concordancia se efectúa en género m: molestos), pero es dominante (la palabra abe ja, en su significado genérico, incluye al macho)". 


\section{A procura dunha linguaxe non sexista. Pragmática do xénero}

Após estas consideracións parécenos claro que o sistema xenérico do galego non é en si mesmo discriminatorio, pois na maior parte dos nomes este morfema gramatical non posúe calquer contido semántico, respondendo en moitas ocasións a unha visión prexuizosa a posíbel identificación entre os xéneros gramaticais e cada un dos sexos (para o cal ten influído, con certeza, o feito de se chamaren os xéneros precisamente 'masculino' e 'feminino'). Contodo, consideramos que para a maioría dos nomes de seres inanimados os falantes non realizan nengunha identificación, nen sequer inconsciente, entre xénero e sexo, de maneira que non é oportuno facer recaír nos utentes da lingua unha obsesión sexual semellante. No tocante á expresión lingüística do sexo, é preciso distinguir, como vimos facendo neste traballo, entre a lexemática e a morfosintáctica. O primeiro tipo está constituído por un número moi reducido de casos (cando menos na clase dos seres humanos), mais detectamos nestes pares opositivos unha forte resistencia á neutralización no singular, probabelmente por seren altas as posibilidades de ambigüidade significativa. Nestas ocasións recoméndase, como afirmamos acima, non utilizar un dos termos do par opositivo no nivel da hiperonimia ('home' por 'ser humano', 'pai' por 'pai e nai', aínda que isto último xa non é frecuente no galego actual), e así mesmo evitar o uso do hipónimo que designa o macho da especie con carácter xenérico, como nos textos medievais que comentamos, escritos por homes desde unha perspectiva excluínte.

Cando a expresión do sexo é morfosintáctica a neutralización sempre se realiza na forma de xénero masculino, provocando tamén nalgunhas ocasións enunciados ambigüos. No que di respeito á relación entre xénero gramatical e sexo nestes pares opositivos, podemos constatar que non é biunívoca, pois se o xénero feminino denota sempre [+ femia], ao sema [- femia] non sempre lle corresponde xénero masculino (García Meseguer 1994: 147). Son diversas as propostas que se teñen feito para evitar o uso de masculinos extensivos, aínda que do noso ponto de vista este masculino gramatical non posúe nengún contido semántico e non é necesariamente discriminatorio, sempre que non se identifique xénero con distinción sexual. A atribución dun sema [- femia] a todo o masculino gramatical pode explicarse, portanto, como un prexuízo (sexista) do ouvinte, sen que debamos interpretar o uso do masculino como un trazo discriminatorio. Esta cuestión lévanos a perguntarnos se non será a propria conciencia sexista do falante quen inflúe na súa percepción das estruturas lingüísticas, pois temos o convencimento de que na realidade calquer forma lingüística pode adquirir os mais diversos significados ou as máis variadas connotacións, sen se precisaren necesariamente mudanzas formais que acompañen as transformacións que experimenta a mentalidade social.

De calquer maneira, algúns trazos formais poden incidir tamén na percepción da realidade por parte dos falantes, tornando visíbel, no caso que nos ocupa, a 
referencia ás mulleres en determinados enunciados. Unha das estratexias propostas para evitar unha linguaxe sexista consiste na utilización das dúas formas, masculinas e femininas, quer através da repetición de todo o substantivo nos dous termos flexionados (galegos e galegas), quer só mediante a duplicación de morfes de xénero (galegos/as), quer através dun novo morfe 'andróxino' (galeg@s). En ocasións, mesmo se defende a utilización da forma feminina en primeiro lugar, utilizando o criterio da orde alfabética, co obxecto de non fomentar a idea de que o feminino deriva do masculino e de construír así un enunciado máis igualitario. Na realidade, o feito de ser o masculino o termo non marcado da oposición semántica non significa que o feminino derive del, polo que unha discusión como esta sobre a orde dos elementos nos parece completamente innecesaria.

Aínda que todas estas propostas teñen como obxectivo a eliminación dese masculino do nivel da hiperonimia, García Meseguer (1994: 158-164) considera que o auténtico problema de ambigüidade semántica, e o maior perigo de interpretación sexista, radica na inexistencia dunha forma particular masculina no nivel da intensión. A súa recomendación, portanto, sería, ao contrario do que resulta habitual, o aditamento sistemático para este nivel do substantivo varón:

En definitiva, el problema del sexismo lingüístico es un problema de espacio ocupado por el varón, en el que la mujer no aparece. Para hacerse presente, la mujer puede escoger entre dos caminos, que, por cierto, no son incompatibles entre sí:

(a) añadir sistemáticamente la forma femenina a la masculina. Es algo así como "respetar el campo del invasor y comparecer junto a él";

(b) añadir el específico a toda palabra o frase que aluda únicamente al varón. Es algo así como "empujar al invasor y obligarle a que se recluya en su territorio.

Sexa cal for a opción utilizada, debemos ter en conta que calquer delas constitúe unha proposta cuxo obxectivo é favorecer a concienciación dos falantes sobre a referencia conxunta a homes e mulleres nun enunciado, sen que se recomende o seu uso sistemático e continuado nun texto longo, pois, para alén de tornalo con frecuencia ilexíbel, a duplicación de formas non é posíbel en todos os casos e non pode evitar a concordancia con adxectivos masculinos neutralizados, como explicamos acima. Neste sentido, a única solución definitiva sería a criación dun terceiro xénero neutro que expresase a indiferenza á oposición sexual, sendo senón inevitábel que un dos dous xéneros disponíbeis acumule dúas funcións, a intensiva e a extensiva. Nun curso práctico de linguaxe administrativa xustifícase así a proposta referente a un enunciado sexista sobre unhas "...prazas de camareira, celador, limpadora, porteiro, subalterno, telefonista”: 
Para evitarmos este uso da linguaxe claramente discriminatorio imos dar unha serie de consellos:

1. Unha das formas de evitármo-lo vicio do exemplo que vimos de ver é o uso das barras (camareiro/a...); sen embargo nunha relación longa este recurso dificulta a lectura do texto e mesmo pode complica-las cousas cando a palabra remate en vocal distinta de o ou a ou en consoante, pois as dúbidas pódennos levar a non saber que facermos con casos como: axente, fiscal ou conserxe.

$[\ldots]$

2. Cando nos refiramos a oficios, cargos ou profesións dunha maneira xenérica, empregaremos sempre o masculino, como forma non marcada da oposición de xénero. No caso que nos ocupa diremos: camareiro, celador, limpador, porteiro, subalterno, telefonista." (Rivas Cid 1994: 41)

No exemplo que se propón neste curso hai cuestións diferentes que merecen comentario. Por unha parte, o sexismo que se denuncia no enunciado reside na identificación prexuizosa entre determinadas profisións e o sexo das persoas que deben exercelas, é portanto a expresión lingüística dunha mentalidade non igualitaria (e, sen dúbida, dunha realidade desigual). Por outra parte, das dúas posibilidades que a lingua oferece para non discriminar por cuestión de sexo, duplicación de formas ou utilización do masculino extensivo, o autor propón a segunda por considerar que con ela se facilita a leitura do texto. A única obxección que poderíamos pór a esta opción é a de permitir unha leitura excluínte, pois o receptor do enunciado pode interpretar ese masculino como inclusivo, hipónimo, e supor que esas prazas de traballo están cobertas ou deben ser cobertas só por homes. Mais talvez nese caso a actitude sexista corresponda ao receptor e non ao emisor, e asente na frecuente confusión entre xénero gramatical e sexo.

Alén diso, Rivas Cid (1994: 41) recomenda neste curso práctico dirixido a funcionarios o uso das barras $(-o /-a)$ en formularios ou documentos que deban ser cobertos polo administrado: Don/Dona, profesor/a ${ }^{22}$. Parece oportuno que sexa así nestes enunciados polo seu carácter referencial; por este motivo pensamos que a recomendación debe estenderse tamén a todos aqueles enunciados dirixidos a unha persoa particular da cal non se coñece o sexo (en cartas comerciais, convocatorias de participación en reunións de órgaos colexiados, etc.); un uso que na realidade está hoxe xa moi estendido.

De acordo co que temos visto anteriormente, podemos concluír que se ben a intervención sobre a lingua pode contribuír a eliminar prexuízos, non se debe

\footnotetext{
22 Todas estas recomendacións de uso recóllense tamén en García Cancela / Díaz Abraira (1991: 84-85).
} 
confiar inxenuamente na utilización de determinadas fórmulas para suprimir actitudes sexistas, xa que por causa da propria flexibilidade e capacidade de adaptación da lingua a intervención sobre un dos seus planos non sempre produce automaticamente noutro os efeitos desexados (Violi 1991: 74-75). Xa vimos, neste sentido, que calquer forma lingüística pode adquirir as máis diversas connotacións, entendendo estas como as asociacións de carácter subxectivo, cultural, ideolóxico, estilístico, etc. que se producen nos significados e que se definen pola súa inestabilidade (Bonfantini 1987). Non consideramos a duplicación de formas nos textos medievais, por exemplo, como índice dunha linguaxe non sexista, senón todo o contrario. De igual modo, as connotacións e significacións que poden adquirir os morfes de xénero teñen causas extralingüísticas que deben ser explicadas (e sobre as cais se debe intervir se queremos acabar con situacións de desigualdade), polo que a utilización dunha marca mórfica nos substantivos non implica por si soa unha linguaxe non sexista, tal como vimos nos casos de estudanta, modista e asistenta. O substantivo feminino poetisa chegou a adquirir certas connotacións negativas, pexorativas, por designar no século XIX a autora dunha determinada lírica 'feminina' inofensiva, que se expresaba nos seráns literarios dos salóns burgueses; como denunciou Rosalía de Castro, representaba a aquelas que cantan as pombas y as frores ( $F N$ 3) demostrando así, na mentalidade da época, teren alma de muller. Talvez por iso, nun cáustico artigo Rosalía (1865) realice entre parénteses a seguinte confesión sobre o substantivo poetisa: "esta palabra ya llegó a hacerme daño". Hoxe hai quen utiliza a forma poeta referida tamén a mulleres, expresando apenas por meio da concordancia a existencia dun morfema feminino (a poeta), encanto outras persoas optan pola reivindicación do termo co morfe feminino -isa (poetisa), co obxecto de o submeter a un proceso de 'rexeneración', descarregándoo de calquer connotación negativa ${ }^{23}$.

Doutra parte, proponse con frecuencia unha estratexia completamente contraria, se ben complementar, a esta da duplicación de formas do nivel da intensión, que consiste en evitar o uso de substantivos que inclúan no seu significado información

\footnotetext{
23 Neste sentido, as estratexias escollidas para loitar contra formas lingüísticas discriminatorias dotadas de connotacións negativas poden ser, aínda que pareza paradoxal, totalmente contrarias. Así, por exemplo, a asunción do termo pexorativo pode ter un marcado carácter de reivindicación. Frente ao termo afro-americana que a political correctness impón nos Estados Unidos para designar persoas de raza negra (ocultando a información racial en favor da referencia á orixe xeográfico-cultural), temos sentido a unha muller africana de lingua portuguesa nun determinado contexto comunicativo autodenominarse preta, como explícita afirmación da súa condición racial, apesar de (ou precisamente por) se preferir habitualmente en portugués o adxectivo negra para designar as persoas desta raza en lugar do máis frecuente adxectivo de cor, que pode ser considerado pexorativo neste uso. Coa denuncia do eufemismo denúnciase á vez a súa causa, neste caso a discriminación racial. En liñas xerais, pensamos que é preciso desconfiarmos non só das propostas, senón da propria operatividade ideolóxica das imposicións do politicamente correcto.
} 
sobre o sexo do referente, substituíndoos por outros colectivos ou abstractos, ou ben por substantivos sen variación xenérica, como persoa:

\begin{tabular}{|c|c|c|}
\hline$\{\text { Masculino }\}_{1}$ & duplicación de formas & colectivos e abstractos \\
\hline $\begin{array}{l}\text { cidadáns }_{1} \\
\text { fillos }_{1} \\
\text { asesores }_{1} \\
\text { licenciados }_{1}\end{array}$ & $\begin{array}{l}\text { cidadáns/ás, cidadáns e cidadás } \\
\text { fillos/as, fillos e fillas } \\
\text { asesores/as, asesores e asesoras } \\
\text { licenciados/as, licenciados e licenciadas }\end{array}$ & $\begin{array}{l}\text { a cidadanía } \\
\text { a descendencia } \\
\text { a asesoría } \\
\text { persoas licenciadas }\end{array}$ \\
\hline
\end{tabular}

A utilización destas formas alternativas ao masculino extensivo non é posíbel en todo o tipo de enunciados, e resultaría innecesaria se tivermos presente que no nivel $_{1}$ o masculino gramatical non transmite nengunha información sobre o sexo, do mesmo xeito que tampouco o fai o feminino do substativo persoa. A función que cumpren estas fórmulas pode interpretarse, portanto, como fundamentalmente concienciadora, e deben ser encadradas nun proceso tendente á superación de todas as discriminacións que se producen en calquer nivel da linguaxe a respeito do sexo. Neste proceso é fundamental, do noso ponto de vista, insistir na distinción entre xénero gramatical e sexo. Ademais, débense denunciar as asimetrías que se producen nos significados (ou nas connotacións) de determinados substantivos e adxectivos segundo o xénero gramatical en que se empregaren (Espiño Amil 1997), tais como home público / muller pública, así como afastar outros usos discriminatorios provocados por unha realidade social desigual. Neste sentido habería que citar a existencia de formas como o substantivo señorita, que así en feminino designa unha muller solteira, mais que non mantén este mesmo significado en masculino (o termo masculino está hoxe, felizmente, en desuso na súa primeira acepción -polo menos, iso cremos-, e consérvase no galego actual como descualificación ou insulto), o cal é índice da importancia que se lle atribuía socialmente á información sobre o estado civil das mulleres, así como do distinto papel que cumpría o matrimonio na vida das persoas de acordo co seu sexo. As proprias mudanzas que experimenta a sociedade, porén, van desterrando xa estes usos. Relacionado co papel social subordinado das mulleres e coa tradicional utilización do apelido do esposo está a frecuente tendencia (posibelmente tamén en retroceso, aínda que plenamente actuante) a identificar a presenza dun home detrás de todo o apelido que se apresenta isoladamente nun texto. Marilar Aleixandre nun dos seus romances menciona nas primeiras páxinas a muller protagonista só polo seu apelido, Seoane, xogando sen dúbida coa ambigüidade e con esa tendencia inconsciente ${ }^{24}$.

${ }^{24}$ Cfr. En cambio Seoane estaba facendo prácticas, cunha bolsa de seis meses, dos que a penas transcorreran dous (p. 19). A non moita distancia do túnel, no centro-algúns dirían no corazón-da cidade, 
O descobrimento da identidade sexual da protagonista oferece ao leitor a posibilidade de reparar no prexuízo.

En resumo, a cuestión do sexismo lingüístico debe ser tratada, na nosa opinión, desde unha perspectiva abranxente que teña en consideración as implicacións ideolóxicas de determinados usos orixinados por comportamentos sociais discriminatorios, tendo en conta que a relación que se estabelece entre lingua e sociedade é de dúas direccións: se ben, por unha parte, a linguaxe sexista é causada por unha mentalidade e un comportamento social androcéntricos, á súa vez constitúe, pola outra, un instrumento que impede tomar conciencia desa realidade, favorecendo a súa perpetuación. Cómpre, portanto, repararmos non apenas nas formas lingüísticas senón, fundamentalmente, nos significados que adquiren, utilizando o procedimento da conmutación para desvelarmos os significados desiguais dos termos masculino e feminino dun mesmo nome (Mey 1985: 364-368) e denunciando as connotacións negativas da forma feminina de certos substantivos. Todo isto sen perdermos de vista que a actuación sobre os usos lingüísticos constitúe máis unha forma de actuación social ${ }^{25}$.

\section{Abreviaturas usadas nos textos literarios, tabeliónicos e xornalísticos citados}

ANT = A Nosa Terra (Periódico galego semanal), Vigo.

Blanco Amor, OGC I = Blanco Amor, Eduardo, Obra en Galego Completa. Narrativa I, Vigo, Galaxia, 1992.

C. E. Ferreiro, OC I = Ferreiro, Celso Emilio, Obra Completa I, Madrid, Arealonga, 1978.

Castelao, Cousas $=$ Castelao, Cousas, Vigo, Galaxia, 1989.

$C G E=$ Luis Filipe Lindley Cintra (ed.), Crónica geral de Espanha de 1344, Lisboa, Imprensa Nacional-Casa da Moeda, 1954, vol. II, citado a partir de Begoña

Seoane comezaba o seu percorrido por unhas rúas que levan nomes de trobadores doutras épocas e que neste tempo están inzadas de bares nos que se pode beber música e escoitar nomes de cervexas e whiskies que parecen escritos por poetas (aínda que Seoane adoita beber ron só ou só tónica, pois non gusta demasiado das mesturas) (A Compañía Clandestina de Contrapublicidade, Vigo, Galaxia, pp. 19-20).

25 "We would argue that language and society cannot be so easily separated. Speech is a form of action, not simply a reflection of underlying social processes. To call people Mrs. or Miss is to help maintain a definition of women which relegates them primarily to family roles. To use he or she, rather than he, for sex-indefinite antecedents is a tangible gesture of including, rather than excluding women from consciousness. Males who consistently interrupt females in conversation are engaging in acts of social domination. In short, verbal and nonverbal communications patterns are not simply epiphenomena; they help establish, transmit, and maintain male dominance. Language chance is obviously not the whole story, but it is certainly a part of social change"(Thorne/ Henley 1978: 29-30). 
Campos Souto / Mar Campos Souto, Prosa histórica, relixiosa e xurídica medieval. Antoloxía, Vigo, AS-PG / A Nosa Terra, 1996.

Curros, $A M T=$ Curros Enríquez, Manuel, Aires da Miña Terra, Latorre y Martínez Editores, Coruña, $1886^{3}$

Demand $a=$ Joseph-Maria Piel / Irene Freire Nunes (eds.), A Demanda do Santo Graal, Lisboa, IN-CM, 1988.

Fole, $A L C=$ Fole, Ánxel, Á lus do candil, Vigo, Galaxia, 1953.

$G E$ = Ramón Martínez López (ed.), General Estoria. Versión gallega del siglo XV, Oviedo, Universidad de Oviedo, 1963, citado a partir de Begoña Campos Souto / Mar Campos Souto, Prosa histórica, relixiosa e xurídica medieval. Antoloxía, Vigo, AS-PG / A Nosa Terra, 1996.

$L C P=$ Ángel Rodríguez González e Isidoro Millán González-Pardo (eds.), Livro do Concello de Pontevedra (1431-1463). Documentos para a historia de Pontevedra medieval, Pontevedra, Museo Provincial de Pontevedra, 1989, citado a partir de Begoña Campos Souto / Mar Campos Souto, Prosa histórica, relixiosa e xurídica medieval. Antoloxía, Vigo, AS-PG / A Nosa Terra, 1996.

LCS = Ángel Rodríguez González (ed.), Libro do concello de Santiago (1416-1422), Santiago de Compostela, Consello da Cultura Galega, 1992, citado a partir de Begoña Campos Souto / Mar Campos Souto, Prosa histórica, relixiosa e xurídica medieval. Antoloxía, Vigo, AS-PG / A Nosa Terra, 1996.

Otero, $M E$ = Otero Pedrayo, Ramón, $O$ mesón dos ermos (edición de Carme Fernández Pérez-Sanjulián), Vigo, AS-PG / A Nosa Terra, 1997.

$P P=$ José de Azevedo Ferreira (ed.), Primeyra Partida. Édition et étude, Braga, Instituto Nacional de Investigação Científica, 1980, citado a partir de Begoña Campos Souto / Mar Campos Souto, Prosa histórica, relixiosa e xurídica medieval. Antoloxía, Vigo, AS-PG / A Nosa Terra, 1996.

Rosalía, $F N$ = Castro, Rosalía de, Follas Novas, La Propaganda Literaria, Habana, 1880. Edición facsimilar da Real Academia Galega, Sada-A Coruña, 1982.

Sarmiento, Coloquio = Sarmiento, F. Martín, "Coloquio de 24 gallegos rústicos", Colección de Voces y Frases de la Lengua Gallega, Salamanca, 1972.

Voz = La Voz de Galicia, A Coruña.

\section{Referencias bibliográficas}

Alpher, B. (1987), "Feminine as the unmarked grammatical gender: Buffalo girls are no fools", Australian Journal of Linguistics 7, 169-187.

Arias Barredo, A. (1995), De feminismo, machismo y género gramatical (El género, un monema no exclusivamente gramatical), Valladolid, Universidad de Valladolid. 
Baron, D. (1986), Grammar and Gender, New Haven and London, Yale University Press.

Bodine, A. (1975), "Androcentrism in prescriptive grammar: singular 'they', sexindefinite 'he' or 'she'", Language in Society 4, 129-146.

Bonfantini, M. A. (1987), “Sobre la connotación”, Estudios de Lingüística 4, 149-158.

Callamard, A. (1998), "Le sexisme á fleur de mots", Le Monde Diplomatique, 15 marzo, 28.

Câmara Jr., J. Mattoso (19744), Princípios de Lingüística Geral, Rio de Janeiro, Livraria Acadêmica.

Campos, M. H. C./ Xavier, M. F. (1991), Sintaxe e semântica do português, Lisboa, Universidade aberta.

Castro, R. de (1865), "Las Literatas. Carta a Eduarda”, Almanaque de Galicia, Lugo, Soto Freire, 56-58.

Corbett, G. G. (1991), Gender, Cambridge, Cambridge University Press.

Coseriu, E. (1981²), Principios de semántica estructural, Madrid, Gredos.

DAE $(1994)=$ Dicionário Aurélio Eletrônico, Rio de Janeiro, Nova Fronteira.

DLP $(1992)=$ Dicionário da Língua Portuguesa, Porto, Porto Editora.

DRAG (1998) = Diccionario da Real Academia Galega, A Coruña, RAG.

Ervin, S. M. (1962), “The Connotations of Gender”, Word 18, 3, 249-261.

Espiño Amil, M. (1997), “Aos señores que fan diccionarios”, Andaina 19, 35-36.

Ferreiro, M. (1997), Gramática histórica galega II. Lexicoloxía, Santiago de Compostela, Laiovento.

Fodor, I. (1959), “The origin of grammatical gender”, Lingua 8, 1-41, 186-214.

Freixeiro Mato, X. R. (1999), Gramática da Lingua Galega III. Semántica, Vigo, A Nosa Terra.

García Cancela, X. / Díaz Abraira, C. L. (1991), Manual de linguaxe administrativa, Santiago de Compostela, Xunta de Galicia.

García Meseguer, A. (1994), ¿Es sexista la lengua española? Una investigación sobre el género gramatical, Madrid, Paidós.

Gonçalves, M. (1995), “Sobre a origem do género”, Diacrítica 10, 117-130.

González Fernández, I. (1978), Sufijos nominales en el gallego actual, Santiago de Compostela, Anexo 11 de Verba.

González Ollé, F. (1981), “La negación expresiva mediante la oposición sintagmática de género gramatical: El tipo sin dineros ni dineras y sus variantes”, Logos 
semantikos IV. Gramática. Studia Lingiiística in honorem E. Coseriu 19211981, Madrid, Gredos, 190-198.

Hasselrot, B. (1950), "Du changement de genre comme moyen d'indiquer une relation de grandeur dans les langues romanes", Vox Romanica 11, 135-147.

Lapa, M. R. (1984"), Estilística da Língua Portuguesa, Coimbra, Coimbra Editora.

Lyons, J. (1971), Introducción en la lingüística teórica, Barcelona, Teide.

Mey, J. L. (1985), Whose language? A study in linguistic pragmatics, Amsterdam, John Benjamins.

Nissen, U. K. (1986), "Sex and gender specification in Spanish", Journal of Pragmatics $10,725-738$.

Porto Dapena, J. A. (1977), El gallego hablado en la comarca ferrolana, Santiago de Compostela, Anexo 9 de Verba.

Rivas Cid, X. (1994), Curso práctico de linguaxe administrativa para funcionarios da Xunta de Galicia, Santiago de Compostela, Xunta de Galicia.

Spender, D. (1979), Man made language, London, Routledge and Kegan Paul.

Spitzer, M. (1941), “Feminización del neutro”, Revista de Filología Hispánica 3, 339371.

Surridge, M. E. (1993), "Gender assignment in french: The hierarchy of rules and the chronology of acquisition", IRAL, 77-95.

Thorne, B. / Henley, N. (1978), "Difference and dominance: an overview of language, gender, and society", in Thorne, B. / Henley, N. (eds.), Language and sex. Difference and dominance, Massachusetts, Newbury House Publishers, 5-42.

Ullmann, S. (19875), Semântica. Uma introdução à ciência do significado, Lisboa, Fundação Calouste Gulbenkian.

Vila Pujol, M.-R. (1989), "Sobre el sustantivo masculino con rasgo de sexo", Anuario de estudios filológicos XII, 311-323.

Violi, P. (1991), El infinito singular, Madrid, Cátedra / Universitat de València / Instituto de la Mujer. 